\title{
In search of convergent regional brain abnormality in cognitive emotion regulation: a transdiagnostic neuroimaging meta-analysis
}

\author{
Tina Khodadadifar ${ }^{\mathrm{a}, \mathrm{b}^{*}}$, Zahra Soltaninejad ${ }^{\mathrm{a}, \mathrm{c}^{*}}$, Amir Ebneabbasi ${ }^{\mathrm{a}}$, Claudia R. Eickhoff ${ }^{\mathrm{d}, \mathrm{e}}$, Christian Sorg ${ }^{\mathrm{f}, \mathrm{g}, \mathrm{h}}$, \\ Thilo Van Eimeren ${ }^{\mathrm{i}, \mathrm{j}}$, Kai Vogeley ${ }^{\mathrm{k}, \mathrm{l}}$, Mojtaba Zarei ${ }^{\mathrm{a}}$, Simon B. Eickhoff ${ }^{\mathrm{d}, \mathrm{m}}$, Masoud Tahmasian ${ }^{\mathrm{a}^{* \star}}$ \\ ${ }^{a}$ Institute of Medical Science and Technology, Shahid Beheshti University, Tehran, Iran \\ b School of Cognitive Sciences, Institute for Research in Fundamental Sciences, Tehran, Iran \\ ${ }^{c}$ Cognitive and Brain science institute, Shahid Beheshti University, Tehran, Iran \\ ${ }^{d}$ Institute of Neuroscience and Medicine (INM-7), Research Center Jülich, Jülich, Germany \\ ${ }^{\mathrm{e}}$ Institute of Clinical Neuroscience and Medical Psychology, Heinrich Heine University Düsseldorf, Düsseldorf, Germany \\ f TUM-Neuroimaging Center (TUM-NIC), Klinikum Rechts der Isar, Technische Universität München, Munich, Germany \\ ${ }^{g}$ Department of Neuroradiology, Klinikum Rechts der Isar, Technische Universität München, Munich, Germany \\ ${ }^{h}$ Department of Psychiatry and Psychotherapy, Klinikum Rechts der Isar, Technische Universität München, Munich, Germany \\ ' Multimodal Neuroimaging Group, Department of Nuclear Medicine, Faculty of Medicine and University Hospital of Cologne, \\ University of Cologne, Germany \\ j Department of Neurology, Faculty of Medicine and University Hospital of Cologne, University of Cologne, Germany \\ k Department of Psychiatry and Psychotherapy, University Hospital Cologne, Cologne, Germany \\ ' Cognitive Neuroscience (INM-3), Institute of Neuroscience and Medicine, Research Center Jülich, Jülich, Germany \\ m Institute for Systems Neuroscience, Medical Faculty, Heinrich-Heine University Düsseldorf, Germany \\ * T.K and Z.S contributed equally to this work.
}

** Corresponding author: Masoud Tahmasian M.D., Ph.D., Institute of Medical Science and Technology, Shahid Beheshti University, Daneshjou Boulevard, Velenjak, P.O. Box 1983969411, Tehran, Iran. Telephone: +98-21-29905803; Fax: +98-21-29902650; Email: $\underline{\mathrm{m} \text { tahmasian@sbu.ac.ir }}$ 


\begin{abstract}
Cognitive emotion regulation (i.e., reappraisal) impairment is a key feature in a wide variety of mental disorders, suggesting common nature of disruption across psychiatric diagnoses. However, the extent of potential shared neurobiological disturbances related to reappraisal impairment is incompletely understood. This study, therefore, aimed to identify neurobiological substrates of disturbed reappraisal using a transdiagnostic approach by performing a quantitative coordinate-based meta-analysis (CBMA) on reappraisal tasks across various mental disorders. Following the best-practice guidelines for neuroimaging meta-analysis, we systematically searched PubMed, ScienceDirect and Web of Science databases for whole-brain neuroimaging studies published through February 2020 that compared brain activation in patients with mental disorders and matched healthy controls during a reappraisal task. Out of 1608 publications, we retrieved 32 publications with 1240 unique individuals, providing sufficient power for conducting CBMA using activation likelihood estimation (ALE) method. The reported peak coordinates for the patient/control difference in selected articles were extracted and several ALE analyses were performed to identify spatial convergence. Surprisingly, neither the pooled ALE analysis nor additional analyses restricting to in-/decreased contrasts and more homogeneous grouping of coordinates (i.e., regulation direction, stimulus valence and disorder category) provided significant convergent findings. This CBMA indicates a lack of convergent regional abnormality related to reappraisal across various mental disorders. This might be due to the complex nature of reappraisal, heterogeneous clinical populations or methodological flexibility including preprocessing and analytical methods.
\end{abstract}




\section{Introduction}

Throughout our daily lives, we are continuously exposed to a wide range of emotionally arousing situations. People do not just passively respond to affective situations, but usually attempt to modulate their subjective emotional experiences. Emotion regulation $(E R)$ is regarded as a bundle of automatic (implicit) or effortful (explicit) processes, which modify the occurrence, intensity and duration of an emotional response (Etkin, et al., 2015; Gross and John, 2003; Phillips, et al., 2008). ER effectiveness is basically related to individuals' emotion awareness, their short- and long-term goals, and their flexibility in selection and implementation of various ER strategies (Gross and Jazaieri, 2014). Cognitive reappraisal (also called 'reappraisal') is among the most effective cognitive ER strategies, which is frequently used for the up/down-regulation of negative and positive affect, in a way we believe would promote the attainment of our goals and needs. Reappraisal is a form of cognitive change that involves reconceptualization of an affective situation and/or its consequences in order to modify its undesired emotional impact. (Etkin, et al., 2015; Kim, et al., 2015; Ochsner, et al., 2012). We apply self-focused reappraisal or "distancing", when we take the perspective of a detached third-person. Alternatively, situation-focused reappraisal requires to re-interpret the meaning, cause and consequences of an emotional event (McRae, et al., 2012a; Ochsner and Gross, 2008).

Successful implementation of reappraisal strategy has been shown to be related to decreased arousal and subjective distress, propitious interpersonal functioning, physical and mental wellbeing and higher quality of life (De Castella, et al., 2013; Gross, et al., 2019; McRae and Gross, 2020; McRae, et al., 2012b). On the other hand, poor reappraisal performance has been demonstrated to have negative effects on mental health and is associated with development, maintenance and lower treatment response of various psychiatric disorders (Aldao, et al., 2010; Jazaieri, et al., 2013; Silvers, et al., 2014). In addition, improving the ER skills increases the effectiveness of psychotherapy (Berking, et al., 2008). These findings indicate that abnormal reappraisal implementation could be considered as a cross-cutting feature of psychopathology across various mental illnesses (Beauchaine and Cicchetti, 2019; Cludius, et al., 2020).

In behavioral experiments, successful reappraisal has been conceptualized as the deliberate change in the self-reported impact (arousal or valance) of an emotional stimulus according to the aim of the given study and the lack of such a change has been defined as the failure in reappraisal. In a typical task, participants are presented with a series of evocative (positive or negative) stimuli such as emotional scenes, facial reactions, memory recalls or distressing events and are instructed to either naturally respond to them or apply the reappraisal strategy to up- or down- 
regulate their emotional response. Participants are generally instructed to use the reappraisal by implementing one of the two principal tactics i.e., reinterpretation or distancing, or they are allowed to choose between them. Subjective rating comes after each condition to estimate the reappraisal effect.

Neuroimaging studies use a similar paradigm to investigate the neural substrates of reappraisal processes in healthy (see e.g., Mulej Bratec, et al., 2015; Mulej Bratec, et al., 2017; Xie, et al., 2016) and clinical populations (see e.g., Larabi, et al., 2018; Heller, et al., 2009). Successful reappraisal in healthy individuals has been shown to depend on the proper interactions between limbic regions, responsible for 'bottom-up' emotional responses and frontoparietal regions, responsible for 'top-down' cognitive control of emotions (Buhle, et al., 2014; Kohn, et al., 2014; Langner, et al., 2018; Morawetz, et al., 2020). However, findings from clinical studies have yielded heterogeneous and often conflicting results (Hofmann, et al., 2012; Zilverstand, et al., 2017).

In the context of these inconsistencies, coordinate-based meta-analysis (CBMA) approaches such as activation likelihood estimation (ALE) provide the possibility to integrate convergent results quantitatively (Eickhoff, et al., 2012) to reveal the common neural substrates underlying psychiatric disorders (Tahmasian, et al., 2019). In particular, the ALE approach allows for the study of large amounts of functional imaging data in a spatially unbiased manner (Eickhoff, et al., 2012).

Previous meta-analyses of emotion processing (McTeague, et al., 2020) and cognitive control tasks (McTeague, et al., 2017) found a transdiagnostic pattern of aberrant activation in the limbic and frontoparietal regions across various psychiatric disorders. Considering these parallel regional disturbances in reappraisal related processes, it is tempting to expect a common pattern of neural disruption underlying reappraisal. Therefore, a CBMA study that exclusively focuses on reappraisal in clinical populations may help to elucidate the nature of impairments. Here, providing a quantitative consolidation of previous neuroimaging works using ALE method, we aimed to identify a transdiagnostic regional abnormality in reappraisal performance by comparing the brain activation in patients with different psychiatric disorders and healthy individuals while doing a reappraisal task.

\section{Methods and Materials}

The current study was pre-registered at the International Prospective Register of Systematic Reviews (PROSPERO, CRD42019119121) and the search strategy was based on the Preferred Reporting Items for Systematic Reviews and Meta-Analyses statement (Moher, et al., 2009). 
Following the most recent best-practice guidelines for neuroimaging meta-analyses (Müller, et al., 2018; Tahmasian, et al., 2019), we performed ALE meta-analyses on existing reappraisal neuroimaging studies that looked for the regulating disturbances in psychiatric patients versus healthy individuals by contrasting the brain activations during the two conditions of reappraisal implementation and natural responding.

\section{Search strategies and selection criteria}

The literature search was conducted in February 2020 through PubMed, ScienceDirect and Web of Science databases with the following search terms: (cognitive OR volitional OR voluntary OR effortful) AND (emotion OR affect) AND (regulat* OR reappraisal OR reinterpretation OR distancing) AND (fMRI OR "functional MRI" OR "functional magnetic resonance imaging" OR PET OR "positron emission tomography") AND (patient OR disorder). Additional publications were identified by reference tracking from reviews/meta-analyses. The resulting pool consisted of 1608 records, assessed by two authors independently (T.K. and Z.S.). Eligible studies were selected in two steps: Firstly, non-English language publications, case-reports, letter to editors, reviews/meta-analyses, and structural or task-free imaging studies were excluded by screening the abstracts. Secondly, full-texts of all remaining studies were screened carefully and studies that met each of the following criteria were included:

- $\mathrm{fMRI} / \mathrm{PET}$ studies that compared the reappraisal task between patients suffering from any kind of mental disorders and healthy subjects,

- if significant brain activation results were reported for the contrast of interest (reappraisal vs. natural responding),

- if "whole-brain" analyses were performed and coordinates from the peak of task-based activations were reported in Montreal Neurological Institute (MNI) (Evans, et al., 1993) or Talairach (Talairach, 1988) spaces,

- if standardized diagnostic criteria (DSM-IV-TR, or DSM-5, or ICD-10) for patient recruitment was used,

- if adult subjects were recruited (range age between 18 and 60),

- if at least seven subjects were in each group.

\section{Data extraction}

For all included studies, we reported sample sizes, demographic data of participants (age, gender), clinical characteristics of patients (diagnosis, diagnostic tool, symptom severity, 
medication status, comorbidities) and experimental setup (stimulus arousal, valence, regulation strategy and direction, imaging modality, scanner type, analysis software package, statistical analysis criteria). In addition, the peak coordinates of between-group experiments for the reappraisal vs. natural responding contrast were extracted (Table 1). Here, "study" reflects an individual publication and "experiment" indicates a set of coordinates belong to a particular analysis or contrast of interest (i.e., patients vs. controls group comparison) in a given study. Subsequently, the experiments were coded as "increased" when the brain activation during the reappraisal condition was higher in patients than healthy controls (patients > controls) or "decreased" when it was lower in patients than controls (patients < controls). The peak coordinates reported in Talairach space were converted into MNI space to set all the coordinates in the same reference space (Lancaster, et al., 2007). To avoid convergence over the analyses performed on the same/overlapping samples (reported within or between studies), we merged the coordinates from multiple experiments (e.g., in-/decreased) pertaining to the studies with the same/overlapping samples, making sure each study contributes once per analysis (Turkeltaub, et al., 2012).

\section{Activation likelihood estimation}

A revised version of activation likelihood estimation (ALE) (Eickhoff, et al., 2012) was used to test whether the activation foci reported in peak coordinates significantly clustered into specific spatial locations, rather than randomly distributed across the whole brain. The ALE analyses were performed in three steps: First, spatial 3D Gaussian probability distributions were modelled around the peak coordinates of activated foci from experiments of interest. The width of the aforementioned probability determines the spatial uncertainty associated with variations in sampling effects, data processing and data analysis. Since the foci of contrasts with smaller sample size have a smaller effect on the modeled uncertainty, it was adjusted for the number of subjects in the smaller group. Then, "modeled activation" maps of all foci of each experiment were pooled into an ALE activation map by computing their overlap across the experiments (Eickhoff, et al., 2012; Turkeltaub, et al., 2012). Finally, the ALE maps were assessed against a nulldistribution map to enable the random-effects inference by using non-linear histogram integration (Eickhoff, et al., 2012; Turkeltaub, et al., 2012). As suggested previously, the above-chance clustering activation foci were assessed by setting the threshold at $p<0.05$ family-wise error at the cluster level (cFWE) to correct for multiple comparisons and avoid spurious findings (Eickhoff, et al., 2017; Müller, et al., 2018). 
To identify transdiagnostic patterns of ER-related abnormalities, multiple ALE analyses were conducted. For the primary analysis, we assessed convergence across all reported effects by pooling all experiments together. Then, we analyzed in-/decreased activations separately, in order to test the direction of aberrant activity. To further investigate the nature of ER dysfunctions, we performed complementary analyses on more homogeneous groups of experiments by categorizing data regarding regulation direction (down- or up-regulation), stimulus valence (negative or positive), disorder category (mood, anxiety, mood and anxiety or others) and reappraisal tactic (reinterpretation or distancing or reinterpretation/distancing) with considering at least 17 experiments in each category to achieve $80 \%$ power for statistical analysis (Eickhoff, et al., 2016). As a result, only the regulation direction (down-regulation), stimulus valence (negative) and disorder category (mood and anxiety) had enough experiments for further valid analyses (Table 2).

\section{Results}

A pool of 1608 records was screened and 107 full-text papers assessed for eligibility. Subsequently, 75 studies were excluded for the following reasons: lacking either heathy controls or group comparison analyses, restricting samples to adolescents or older adults, not analyzing the whole brain, reporting non-significant group comparisons, and including individuals at a high-risk of mental illnesses or with subclinical diagnosis (Table S1). Finally, a total of 32 publications were included in our meta-analysis (Figure 1), with three overlapping samples that were reported in multiple publications, one sample was used in three papers (Larabi, et al., 2018; van der Meer, et al., 2014; Zhang, et al., 2020), and two samples each used in a pair of papers (Goldin, et al., 2009a; Heller, et al., 2009; Johnstone, et al., 2007; Ziv, et al., 2013). As mentioned earlier, we rigorously avoided convergence over analyses performed on the same samples both within and across papers. Accordingly, we merged all studies with overlapping samples that resulted in 28 independent samples. Demographical, clinical and experimental characteristics of the included papers are shown in Table 1. Overall, we conducted several separate ALE metaanalyses. Neither our primary, nor complementary ALE meta-analyses yielded significant results for the following domains: (i) Task [reappraisal: 28 experiments $(p=.418)$, reappraisal-decreased: 21 experiments $(p=.570)$ and reappraisal-increased: 20 experiments $(p=.832)$; (ii) Regulation direction [down-regulation: 27 experiments $(p=.859)$ ]; (iii) Stimulus valence [negative: 28 experiments $(p=.930)$ ]; (iv) Disorder category [mood and anxiety: $20(p=.076)$ ]. Of note, 
repeating all analyses with a more liberal statistical threshold (i.e., threshold-free cluster enhancement, TFCE) demonstrated no significant convergence as well (Table 2). Figure 2 displays the sporadic distribution of foci based on the reappraisal experiments across literature.

\section{Discussion}

This study aimed to answer the ongoing dispute i.e., whether there is a convergent regional brain abnormality during reappraisal performance across various mental disorders. Following the bestpractice guidelines for neuroimaging meta-analysis and using a strict statistical approach for multiple comparison correction, we did not find any consistent findings in our main ALE-based meta-analysis and sub-analyses, despite a comparably high homogeneity of the applied tasks (i.e., reappraisal). Of note, some previous inquiries on the neural alterations of various neuropsychiatric disorders did not reveal spatial convergence either (Giehl, et al., 2019; Muller, et al., 2017; Nickl-Jockschat, et al., 2015; Samea, et al., 2019; Tahmasian, et al., 2018a). This variance, if not completely attributable to the methodological divergence in neuroimaging and/or heterogeneity in clinical populations (Tahmasian, et al., 2018b), suggests that underlying domains of emotion and cognition are differently impaired across mental disorders. Importantly, distinct psychopathology of impaired reappraisal across different clinical populations was previously highlighted (D'Agostino, et al., 2017; Taylor and Liberzon, 2007). We discuss further this heterogeneity in the next section.

\section{The potential reasons of divergent findings}

\section{i. Distinct pathophysiology of impaired reappraisal}

Theoretically, dysfunctional ER may take place in different stages including the identification of regulation necessity, selection of regulatory strategy, implementation of selected strategy, and stopping/switching of implemented process (Fernandez, et al., 2016; Gross, et al., 2019). Indeed, clinical conditions are characterized by abnormalities in one or more regulatory stages, and may not involve disruptions in common brain regions. For example, depression is involved with overestimation of mood-congruent stimuli, as apparent in differential amygdala activity (Zilverstand, et al., 2017) and conversely, a helplessness to ignite a regulatory action (Sheppes, et al., 2015). Bipolar patients overvalue the hedonic benefits of manic states and are not usually convinced to down-regulate the positive affect (Fernandez, et al., 2016). Moreover, anxiety is associated with attentional biases toward threat stimuli as reflected in differential activity of 
parietal lobule (Zilverstand, et al., 2017) and consequently, an amplified representation of regulation urgency (Gross and Jazaieri, 2014). Exaggerated sense of regulation necessity and decreased flexibility in strategy selection are mainly observed in post-traumatic stress disorder (PTSD) and obsessive-compulsive disorder (OCD) (Taylor and Liberzon, 2007). Additionally, patients with social anxiety disorder (SAD) may be uncertain about the effectiveness of reappraisal implementation due to insufficient self-efficacy, which probably results in premature stopping of regulatory effort (Sheppes, et al., 2015). Borderline personality disorder is also associated with monitoring deficits of impulsive strategy switching (Gross, et al., 2019). Furthermore, failing to stop the maladaptive strategies (e.g., rumination) may affect the implementation of adaptive ones (e.g., reappraisal) in depression and anxiety disorders (Dryman and Heimberg, 2018). All these examples show that differences in clinical populations regarding the awareness of emotions, beliefs about controllability of emotions, tendency to regulate emotions and availability of regulatory resources (Kim, et al., 2015) are critical factors influencing the successful reappraisal performance, and probably, the pertinent neural engagement.

\section{ii. Experimental flexibility}

Absence of convergent regional abnormality due to reappraisal impairment can be further explained by the taxonomy of experimental designs in neuroimaging studies of reappraisal. Although we only included studies which used the prototypical reappraisal paradigm, some experimental factors and underlying cognitive functions could well affect the neural basis of cognitive reappraisal. Attentional engagement is a relevant example which can be modulated with interrelated exogenous e.g., arousal and valence (Sussman, et al., 2013) and endogenous factors e.g., needs, goals and motivations (Ochsner and Gross, 2005). Remarkably, reappraisal of higharousal stimuli involves greater cognitive demands (Ortner, et al., 2016), as appeared in differential prefrontal recruitment (Silvers, et al., 2015). Unfortunately, the majority of our included studies have not reported the mean arousal of presented stimuli (63\%). Relatedly, various negative stimuli (e.g., sad, disgust, and fearful) are reported to reflect similar arousals, but involve different emotion processing networks (Fusar-Poli, et al., 2009) and thereby, they probably engage distinct regulatory circuitries. Particularly, disorder-relevant stimuli are expected to be more motivationally salient than irrelevant ones. For example, reappraisal of social threats in SAD individuals involves excessive neural disturbances compared with physical threats (Goldin, et al., 2009b). Again, most of the included studies have not reported disorder-relevancy of presented stimuli (81\%). Importantly, high burdens of down-regulating salient stimuli may be facilitated with a concurrent distraction strategy (Sheppes, et al., 2014), which activates the broader regulatory networks. Unfortunately, most of the included studies have not measured attentional engagement 
during reappraisal using pupil dilation (94\%), which cannot provide enough evidence regarding the substantial variance on regulatory brain circuits caused by attention deployment. Thus, at least a part of non-replicable results may stem from uncontrolled moderating factors related to external heterogeneous stimuli and/or internal diverse representations.

\section{iii. Heterogeneous clinical populations}

Clinical discrepancy of patients can be another important confounder causing divergent neuroimaging results. For instance, $31 \%$ of our included studies were medicated (only $9 \%$ lifetime drug-naïve). Meanwhile, the modulatory role of psychotropic medications on the emotional brain circuitries have been widely accepted (Roiser and Sahakian, 2013). Moreover, $19 \%$ of our studies were single-sex investigations. Again, gender difference entails neural differences in emotional reactivity and regulation (McRae, et al., 2008; Whittle, et al., 2011), including interactions between diagnosis and biological sex. Heterogeneous clinical entities of disorders should be also accounted for. As an example, MDD ( $25 \%$ of our included studies) is diagnosed by considering the presence of at least five of nine symptoms. Hence, it may present itself in a number of variants with different somatic/emotional/cognitive clinical states and a variety of pertinent neural disturbances (Rive, et al., 2013). Additionally, our included samples of a particular diagnosis (e.g., depression) had wide range of symptom severity and clinical status (e.g., acute, chronic, remitted), which clearly affects the quality/quantity of reappraisal-related brain activation (Dixon, et al., 2020; Stephanou, et al., 2017). Thus, such heterogeneity in clinical/demographical characteristics of patients may importantly contribute to the inconsistent finding in neural correlates of impaired reappraisal.

\section{iv. Flexible methodology}

Methodological flexibility in neuroimaging studies (e.g., image acquisition, preprocessing, software and analysis pipeline) (Bowring, et al., 2019; Kharabian Masouleh, et al., 2019) could also explain our null findings. In a very recent neuroimaging study, 70 independent teams analyzed the same dataset and interestingly, even no two teams performed identical analysis workflows. This analytical flexibility in neuroimaging had noticeable effects on the reported results and their interpretation (Botvinik-Nezer, et al., 2020). As a relevant example in our work, $16 \%$ of included studies have not applied any correction for multiple comparisons, which might produce non-replicable spurious findings. Moreover, the remaining $84 \%$ studies have not followed similar methodological approaches [78\% of them used family-wise error (FWE) and $6 \%$ false-discovery rate (FDR)]. It is worthy to mention that FWE is statistically more conservative than FDR (Bennett, et al., 2009; Han and Glenn, 2018). Moreover, the included FWE-corrected results have not been 
similarly calculated [ $59 \%$ with Monte Carlo simulation (MCS) and $19 \%$ with random field theory (RFT)]. The RFT seems to have less FWE rates than MCS (Nichols, 2012). Additionally, the MCS studies have not been analyzed alike [40\% AFNI (34\% version < 2017, 6\% version > 2017 and $19 \%$ non-AFNI software]. Indeed, a 15-year-old bug in the AFNI's MCS has been inflated falsepositive rates, which was fixed later in 2017 (Cox, et al., 2017). Put together, the observed heterogeneity in reappraisal literature might be due to methodological diversity.

\section{v. Questionable research practices and publication bias}

Another explanation could be that the anticipated effect might not be so stringent, as hypothesized. As a matter of fact, scales are usually tipped in favor of publishing positive results. This provides the wrong motivations to manipulate the analytical parameters in order to obtain the significant relations, which sometimes leads to spurious findings. Thus, at least in some cases, the "faithful" reappraisal disturbances in clinical populations could have resulted from a biased overestimation. For instance, there is some evidences that MDD patients are able to efficiently use reappraisal, when they "explicitly trained to do so" (Ebneabbasi, 2020; Liu and Thompson, 2017). Several neuroimaging studies also reported the intact neural underpinning of reappraisal in MDD (Davis, et al., 2018; Doré, et al., 2018; Loeffler, et al., 2019; Rubin-Falcone, et al., 2020; Rubin-Falcone, et al., 2018). Importantly, when non-significant results are published, they are not usually entered in ALE meta-analyses. Indeed, insensitivity of ALE to non-significant results helps to increase the publication bias (Acar, et al., 2018). Notably, we excluded 22 eligible studies due to non-significant group comparisons results.

\section{Collation with previous meta-analyses}

Following the best-practice guideline for neuroimaging meta-analysis (Müller, et al., 2018; Tahmasian, et al., 2019) and rigorous methodological approach, our null result is expected to reflect a representation of the existing reappraisal studies across psychiatric disorders and should not be attributable to a lack of statistical power or statistical issues. Strikingly, we had some methodological differences with two previous ER meta-analyses on mood and anxiety disorders (Pico-Perez, et al., 2017) and various anxiety disorders (Wang, et al., 2018). Firstly, those metaanalyses used effect size signed differential mapping (ES-SDM), which is statistically more lenient than ALE. A previous simulation study showed that an uncorrected threshold of $p=.005$ and SDM$Z>1$ adequately controlled the probability of detecting an effect by chance (Radua, et al., 2012). However, this is an informal control of the false positive rate and may be too conservative or too liberal in other datasets. Secondly, here, we included 32 studies, comparing to substantially smaller number of studies in previous meta-analyses i.e., eight studies (Wang, et al., 2018) or 13 
studies (Pico-Perez, et al., 2017). Of note, each of those meta-analyses included two nonsignificant studies. Thus, significant convergence might be driven by only few experiments. Thirdly, we applied stringent exclusion criteria compared with previous work that entered two noneligible studies i.e., one non-whole-brain and one adolescence (Pico-Perez, et al., 2017). Fourthly, our search was not restricted to mood and anxiety disorders, and thereby, additional relevant disorders were covered.

\section{Limitations and recommendations for future studies}

Our study has some limitations. First, the number of patients in the included studies differed substantially across the psychiatric groups (e.g., $n=196$ in MDD and $n=17$ in substance use disorder and gambling disorder). The disproportionate share of coordinates, therefore, may affect the sensitivity of results to have a bias towards the clinical characteristics of larger groups. Moreover, none of the particular patient groups reached the minimum number of experiments to obtain the sufficient power for ALE analysis, which forecloses further representing the pathologically related differences in brain activation. In fact, beside pooled (ALL experiments) and between-group (patient<control and patient>control) contrasts, there were sufficient experiments only for few groupings of experiment (e.g., mood and anxiety) (Table 2), which restricts our understanding of reappraisal related difficulties across different diagnoses in spite of the task specificity. These notable limitations necessitate further studies on different psychiatric patient groups by using larger sample sizes and standard methodology ideally through collaborations to ameliorate site-idiosyncrasies, as well as sharing data openly to allow replication and future integration. Furthermore, to differentiate a true lack of localized consistency from clinical/methodological divergence, we propose the following recommendations for future clinicalneuroimaging studies: 1) investigate the neural correlates of model-driven/stage-based regulatory dysfunctions in clinical populations; 2) design the reappraisal experiments considering the experimental moderating factors such as stimulus features (e.g., valence, arousal and relevancy to disorder); 3) clearly report clinical (e.g., comorbidity, medication, age/gender and symptom severity) as well as methodological (e.g., preprocessing, software and analysis pipeline) characteristics for replication feasibility; and, 4) utilize stringent statistical thresholds to minimize the potential non-replicable spurious results.

\section{Conclusion}

The present meta-analysis demonstrated that the existing literature on emotion dysregulation has not yielded consistent, localized and cross-cutting neural anomaly during reappraisal 
performance. We highlighted the distinct psychopathology of impaired reappraisal across different clinical populations, as well as divergent experimental, clinical and methodological factors that could explain our null results. This study, along with other transdiagnostic researches (Bagherzadeh-Azbari, et al., 2019; Goodkind, et al., 2015; Janiri, et al., 2020; McTeague, et al., 2016; Opel, et al., 2020; Schwartz, et al., 2019; Shao, et al., 2012) emphasizes the identification of concordant transdiagnostic abnormalities using task-based and resting-state neuroimaging methods. Such a transdiagnostic approach is necessary to guide the future studies and to refine and improve the current classification and treatment of mental disorders (Fusar-Poli, et al., 2019). For upcoming researches, searching for the potential neural congruency underlying various aspects of disturbances in emotional processing and regulation is promising.

\section{Acknowledgements}

SBE was supported by the Deutsche Forschungsgemeinschaft (DFG, El 816/21-1), the National Institute of Mental Health (R01-MH074457), and the European Union's Horizon 2020 Research and Innovation Programme under Grant Agreement No. 945539 (HBP SGA3).

\section{Conflict of interest}

The authors declare that the research was conducted in the absence of any commercial or financial relationships that could be construed as a potential conflict of interest. 


\section{References}

Acar, F., Seurinck, R., Eickhoff, S.B., Moerkerke, B. (2018) Assessing robustness against potential publication bias in activation likelihood estimation (ALE) meta-analyses for fMRI. PloS one, 13.

Albein-Urios, N., Verdejo-Roman, J., Asensio, S., Soriano-Mas, C., Martinez-Gonzalez, J.M., VerdejoGarcia, A. (2014) Re-appraisal of negative emotions in cocaine dependence: dysfunctional corticolimbic activation and connectivity. Addict Biol, 19:415-26.

Aldao, A., Nolen-Hoeksema, S., Schweizer, S. (2010) Emotion-regulation strategies across psychopathology: A meta-analytic review. Clinical Psychology Review, 30:217-237.

Bagherzadeh-Azbari, S., Khazaie, H., Zarei, M., Spiegelhalder, K., Walter, M., Leerssen, J., Van Someren, E.J.W., Sepehry, A.A., Tahmasian, M. (2019) Neuroimaging insights into the link between depression and Insomnia: A systematic review. J Affect Disord, 258:133-143.

Ball, T.M., Ramsawh, H.J., Campbell-Sills, L., Paulus, M.P., Stein, M.B. (2013) Prefrontal dysfunction during emotion regulation in generalized anxiety and panic disorders. Psychol Med, 43:1475-86.

Beauchaine, T.P., Cicchetti, D. (2019) Emotion dysregulation and emerging psychopathology: A transdiagnostic, transdisciplinary perspective. Development and psychopathology, 31:799-804.

Bennett, C.M., Wolford, G.L., Miller, M.B. (2009) The principled control of false positives in neuroimaging. Social cognitive and affective neuroscience, 4:417-422.

Berking, M., Wupperman, P., Reichardt, A., Pejic, T., Dippel, A., Znoj, H. (2008) Emotion-regulation skills as a treatment target in psychotherapy. Behaviour research and therapy, 46:1230-7.

Blair, K.S., Geraci, M., Smith, B.W., Hollon, N., DeVido, J., Otero, M., Blair, J.R., Pine, D.S. (2012) Reduced dorsal anterior cingulate cortical activity during emotional regulation and top-down attentional control in generalized social phobia, generalized anxiety disorder, and comorbid generalized social phobia/generalized anxiety disorder. Biol Psychiatry, 72:476-82.

Botvinik-Nezer, R., Holzmeister, F., Camerer, C.F., Dreber, A., Huber, J., Johannesson, M., Kirchler, M., Iwanir, R., Mumford, J.A., Adcock, R.A., Avesani, P., Baczkowski, B.M., Bajracharya, A., Bakst, L., Ball, S., Barilari, M., Bault, N., Beaton, D., Beitner, J., Benoit, R.G., Berkers, R.M.W.J., Bhanji, J.P., Biswal, B.B., Bobadilla-Suarez, S., Bortolini, T., Bottenhorn, K.L., Bowring, A., Braem, S., Brooks, H.R., Brudner, E.G., Calderon, C.B., Camilleri, J.A., Castrellon, J.J., Cecchetti, L., Cieslik, E.C., Cole, Z.J., Collignon, O., Cox, R.W., Cunningham, W.A., Czoschke, S., Dadi, K., Davis, C.P., Luca, A.D., Delgado, M.R., Demetriou, L., Dennison, J.B., Di, X., Dickie, E.W., Dobryakova, E., Donnat, C.L., Dukart, J., Duncan, N.W., Durnez, J., Eed, A., Eickhoff, S.B., Erhart, A., Fontanesi, L., Fricke, G.M., Fu, S., Galván, A., Gau, R., Genon, S., Glatard, T., Glerean, E., Goeman, J.J., Golowin, S.A.E., González-García, C., Gorgolewski, K.J., Grady, C.L., Green, M.A., Guassi Moreira, J.F., Guest, O., Hakimi, S., Hamilton, J.P., Hancock, R., Handjaras, G., Harry, B.B., Hawco, C., Herholz, P., Herman, G., Heunis, S., Hoffstaedter, F., Hogeveen, J., Holmes, S., Hu, C.-P., Huettel, S.A., Hughes, M.E., lacovella, V., Iordan, A.D., Isager, P.M., Isik, A.I., Jahn, A., Johnson, M.R., Johnstone, T., Joseph, M.J.E., Juliano, A.C., Kable, J.W., Kassinopoulos, M., Koba, C., Kong, X.Z., Koscik, T.R., Kucukboyaci, N.E., Kuhl, B.A., Kupek, S., Laird, A.R., Lamm, C., Langner, R., Lauharatanahirun, N., Lee, H., Lee, S., Leemans, A., Leo, A., Lesage, E., Li, F., Li, M.Y.C., Lim, P.C., Lintz, E.N., Liphardt, S.W., Losecaat Vermeer, A.B., Love, B.C., Mack, M.L., Malpica, N., Marins, T., Maumet, C., McDonald, K., McGuire, J.T., Melero, H., Méndez Leal, A.S., Meyer, B., Meyer, K.N., Mihai, G., Mitsis, G.D., Moll, J., Nielson, D.M., Nilsonne, G., Notter, M.P., Olivetti, E., Onicas, A.I., Papale, P., Patil, K.R., Peelle, J.E., Pérez, A., Pischedda, D., Poline, J.-B., Prystauka, Y., Ray, S., Reuter-Lorenz, P.A., Reynolds, R.C., Ricciardi, E., Rieck, J.R., Rodriguez-Thompson, A.M., Romyn, A., Salo, T., Samanez-Larkin, G.R., Sanz-Morales, E., Schlichting, M.L., Schultz, 
D.H., Shen, Q., Sheridan, M.A., Silvers, J.A., Skagerlund, K., Smith, A., Smith, D.V., SokolHessner, P., Steinkamp, S.R., Tashiian, S.M., Thirion, B., Thorp, J.N., Tinghög, G., Tisdall, L., Tompson, S.H., Toro-Serey, C., Torre Tresols, J.J., Tozzi, L., Truong, V., Turella, L., van 't Veer, A.E., Verguts, T., Vettel, J.M., Vijayarajah, S., Vo, K., Wall, M.B., Weeda, W.D., Weis, S., White, D.J., Wisniewski, D., Xifra-Porxas, A., Yearling, E.A., Yoon, S., Yuan, R., Yuen, K.S.L., Zhang, L., Zhang, X., Zosky, J.E., Nichols, T.E., Poldrack, R.A., Schonberg, T. (2020) Variability in the analysis of a single neuroimaging dataset by many teams. Nature.

Bowring, A., Maumet, C., Nichols, T.E. (2019) Exploring the impact of analysis software on task fMRI results. Human brain mapping, 40:3362-3384.

Buhle, J.T., Silvers, J.A., Wager, T.D., Lopez, R., Onyemekwu, C., Kober, H., Weber, J., Ochsner, K.N. (2014) Cognitive reappraisal of emotion: a meta-analysis of human neuroimaging studies. Cerebral cortex, 24:2981-2990.

Butler, O., Willmund, G., Gleich, T., Zimmermann, P., Lindenberger, U., Gallinat, J., Kühn, S. (2018) Cognitive Reappraisal and Expressive Suppression of Negative Emotion in Combat-Related Posttraumatic Stress Disorder: A Functional MRI Study. Cognitive Therapy and Research, 43:236246.

Campbell-Sills, L., Simmons, A.N., Lovero, K.L., Rochlin, A.A., Paulus, M.P., Stein, M.B. (2011) Functioning of neural systems supporting emotion regulation in anxiety-prone individuals. Neuroimage, 54:68996.

Cludius, B., Mennin, D., Ehring, T. (2020) Emotion regulation as a transdiagnostic process. Emotion (Washington, D.C.), 20:37-42.

Cox, R.W., Chen, G., Glen, D.R., Reynolds, R.C., Taylor, P.A. (2017) FMRI Clustering in AFNI: FalsePositive Rates Redux. Brain Connectivity, 7:152-171.

D’Agostino, A., Covanti, S., Monti, M.R., Starcevic, V. (2017) Reconsidering emotion dysregulation. Psychiatric Quarterly, 88:807-825.

Davis, E.G., Foland-Ross, L.C., Gotlib, I.H. (2018) Neural correlates of top-down regulation and generation of negative affect in major depressive disorder. Psychiatry Research: Neuroimaging, 276:1-8.

De Castella, K., Goldin, P., Jazaieri, H., Ziv, M., Dweck, C.S., Gross, J.J. (2013) Beliefs about emotion: Links to emotion regulation, well-being, and psychological distress. Basic and Applied Social Psychology, 35:497-505.

Dixon, M.L., Moodie, C.A., Goldin, P.R., Farb, N., Heimberg, R.G., Gross, J.J. (2020) Emotion Regulation in Social Anxiety Disorder: Reappraisal and Acceptance of Negative Self-beliefs. Biological Psychiatry: Cognitive Neuroscience and Neuroimaging, 5:119-129.

Doré, B.P., Rodrik, O., Boccagno, C., Hubbard, A., Weber, J., Stanley, B., Oquendo, M.A., Miller, J.M., Sublette, M.E., Mann, J.J. (2018) Negative autobiographical memory in depression reflects elevated amygdala-hippocampal reactivity and hippocampally associated emotion regulation. Biological Psychiatry: Cognitive Neuroscience and Neuroimaging, 3:358-366.

Dryman, M.T., Heimberg, R.G. (2018) Emotion regulation in social anxiety and depression: A systematic review of expressive suppression and cognitive reappraisal. Clinical psychology review, 65:17-42.

Ebneabbasi, A., Mahdipour, M., Nejati, V., Li, M., Liebe, T., Colic, L., Leutritz, A.L., Vogel, M., Zarei, M., Walter, M., Tahmasian, M. (2020) Emotion processing and regulation in major depressive disorder: A 7 T resting-state fMRI stud. PsyArXiv. 
Eickhoff, S.B., Bzdok, D., Laird, A.R., Kurth, F., Fox, P.T. (2012) Activation likelihood estimation metaanalysis revisited. Neuroimage, 59:2349-2361.

Eickhoff, S.B., Laird, A.R., Fox, P.M., Lancaster, J.L., Fox, P.T. (2017) Implementation errors in the GingerALE Software: description and recommendations. Human brain mapping, 38:7-11.

Eickhoff, S.B., Nichols, T.E., Laird, A.R., Hoffstaedter, F., Amunts, K., Fox, P.T., Bzdok, D., Eickhoff, C.R. (2016) Behavior, sensitivity, and power of activation likelihood estimation characterized by massive empirical simulation. Neuroimage, 137:70-85.

Etkin, A., Buchel, C., Gross, J.J. (2015) The neural bases of emotion regulation. Nat Rev Neurosci, 16:693700 .

Evans, A.C., Collins, D.L., Mills, S., Brown, E., Kelly, R., Peters, T.M. (3D statistical neuroanatomical models from $305 \mathrm{MRI}$ volumes). In; 1993. IEEE. p 1813-1817.

Fernandez, K.C., Jazaieri, H., Gross, J.J. (2016) Emotion regulation: a transdiagnostic perspective on a new RDoC domain. Cognitive Therapy and Research, 40:426-440.

Fusar-Poli, P., Placentino, A., Carletti, F., Landi, P., Allen, P., Surguladze, S., Benedetti, F., Abbamonte, M., Gasparotti, R., Barale, F. (2009) Functional atlas of emotional faces processing: a voxel-based meta-analysis of 105 functional magnetic resonance imaging studies. Journal of psychiatry \& neuroscience.

Fusar-Poli, P., Solmi, M., Brondino, N., Davies, C., Chae, C., Politi, P., Borgwardt, S., Lawrie, S.M., Parnas, J., McGuire, P. (2019) Transdiagnostic psychiatry: a systematic review. World Psychiatry, 18:192207.

Giehl, K., Tahmasian, M., Eickhoff, S.B., van Eimeren, T. (2019) Imaging executive functions in Parkinson's disease: An activation likelihood estimation meta-analysis. Parkinsonism Relat Disord.

Goldin, P.R., Manber-Ball, T., Werner, K., Heimberg, R., Gross, J.J. (2009a) Neural mechanisms of cognitive reappraisal of negative self-beliefs in social anxiety disorder. Biol Psychiatry, 66:1091-9.

Goldin, P.R., Manber, T., Hakimi, S., Canli, T., Gross, J.J. (2009b) Neural bases of social anxiety disorder: emotional reactivity and cognitive regulation during social and physical threat. Archives of general psychiatry, 66:170-180.

Goodkind, M., Eickhoff, S.B., Oathes, D.J., Jiang, Y., Chang, A., Jones-Hagata, L.B., Ortega, B.N., Zaiko, Y.V., Roach, E.L., Korgaonkar, M.S., Grieve, S.M., Galatzer-Levy, I., Fox, P.T., Etkin, A. (2015) Identification of a common neurobiological substrate for mental illness. JAMA Psychiatry, 72:30515.

Greening, S.G., Osuch, E.A., Williamson, P.C., Mitchell, D.G. (2014) The neural correlates of regulating positive and negative emotions in medication-free major depression. Soc Cogn Affect Neurosci, 9:628-37.

Gross, J.J., Jazaieri, H. (2014) Emotion, emotion regulation, and psychopathology: An affective science perspective. Clinical Psychological Science, 2:387-401.

Gross, J.J., John, O.P. (2003) Individual differences in two emotion regulation processes: Implications for affect, relationships, and well-being. Journal of Personality and Social Psychology, 85:348-362.

Gross, J.J., Uusberg, H., Uusberg, A. (2019) Mental illness and well-being: an affect regulation perspective. World Psychiatry, 18:130-139. 
Han, H., Glenn, A.L. (2018) Evaluating methods of correcting for multiple comparisons implemented in SPM12 in social neuroscience fMRI studies: an example from moral psychology. Social neuroscience, 13:257-267.

Heller, A.S., Johnstone, T., Shackman, A.J., Light, S.N., Peterson, M.J., Kolden, G.G., Kalin, N.H., Davidson, R.J. (2009) Reduced capacity to sustain positive emotion in major depression reflects diminished maintenance of fronto-striatal brain activation. Proc Natl Acad Sci U S A, 106:2244550 .

Hofmann, S.G., Sawyer, A.T., Fang, A., Asnaani, A. (2012) Emotion dysregulation model of mood and anxiety disorders. Depress Anxiety, 29:409-16.

Janiri, D., Moser, D.A., Doucet, G.E., Luber, M.J., Rasgon, A., Lee, W.H., Murrough, J.W., Sani, G., Eickhoff, S.B., Frangou, S. (2020) Shared Neural Phenotypes for Mood and Anxiety Disorders: A Meta-analysis of 226 Task-Related Functional Imaging Studies. JAMA Psychiatry, 77:172-179.

Jazaieri, H., Urry, H.L., Gross, J.J. (2013) Affective disturbance and psychopathology: An emotion regulation perspective. Journal of Experimental Psychopathology, 4:584-599.

Johnstone, T., van Reekum, C.M., Urry, H.L., Kalin, N.H., Davidson, R.J. (2007) Failure to regulate: counterproductive recruitment of top-down prefrontal-subcortical circuitry in major depression. $\mathrm{J}$ Neurosci, 27:8877-84.

Kharabian Masouleh, S., Eickhoff, S.B., Hoffstaedter, F., Genon, S., Alzheimer's Disease Neuroimaging, I. (2019) Empirical examination of the replicability of associations between brain structure and psychological variables. Elife, 8.

Kim, M.Y., Bigman, Y., Tamir, M. (2015) Emotional regulation.

Koenigsberg, H.W., Fan, J., Ochsner, K.N., Liu, X., Guise, K.G., Pizzarello, S., Dorantes, C., Guerreri, S., Tecuta, L., Goodman, M., New, A., Siever, L.J. (2009) Neural correlates of the use of psychological distancing to regulate responses to negative social cues: a study of patients with borderline personality disorder. Biol Psychiatry, 66:854-63.

Kohn, N., Eickhoff, S.B., Scheller, M., Laird, A.R., Fox, P.T., Habel, U. (2014) Neural network of cognitive emotion regulation - An ALE meta-analysis and MACM analysis. Neurolmage, 87:345-355.

Lancaster, J.L., Tordesillas-Gutiérrez, D., Martinez, M., Salinas, F., Evans, A., Zilles, K., Mazziotta, J.C., Fox, P.T. (2007) Bias between MNI and Talairach coordinates analyzed using the ICBM-152 brain template. Human brain mapping, 28:1194-1205.

Langner, R., Leiberg, S., Hoffstaedter, F., Eickhoff, S.B. (2018) Towards a human self-regulation system: Common and distinct neural signatures of emotional and behavioural control. Neuroscience \& Biobehavioral Reviews, 90:400-410.

Larabi, D.I., van der Meer, L., Pijnenborg, G.H.M., Curcic-Blake, B., Aleman, A. (2018) Insight and emotion regulation in schizophrenia: A brain activation and functional connectivity study. Neuroimage Clin, 20:762-771.

Liu, D.Y., Thompson, R.J. (2017) Selection and implementation of emotion regulation strategies in major depressive disorder: An integrative review. Clinical psychology review, 57:183-194.

Loeffler, L.A.K., Satterthwaite, T.D., Habel, U., Schneider, F., Radke, S., Derntl, B. (2019) Attention control and its emotion-specific association with cognitive emotion regulation in depression. Brain imaging and behavior, 13:1766-1779. 
McRae, K., Ciesielski, B., Gross, J.J. (2012a) Unpacking cognitive reappraisal: goals, tactics, and outcomes. Emotion, 12:250.

McRae, K., Gross, J.J. (2020) Emotion regulation. Emotion, 20:1.

McRae, K., Jacobs, S.E., Ray, R.D., John, O.P., Gross, J.J. (2012b) Individual differences in reappraisal ability: Links to reappraisal frequency, well-being, and cognitive control. Journal of Research in Personality, 46:2-7.

McRae, K., Ochsner, K.N., Mauss, I.B., Gabrieli, J.J., Gross, J.J. (2008) Gender differences in emotion regulation: An fMRI study of cognitive reappraisal. Group processes \& intergroup relations, 11:143162.

McTeague, L.M., Goodkind, M.S., Etkin, A. (2016) Transdiagnostic impairment of cognitive control in mental illness. Journal of psychiatric research, 83:37-46.

McTeague, L.M., Goodkind, M.S., Etkin, A. (2017) Transdiagnostic impairment of cognitive control in mental illness. Journal of psychiatric research, 83:37-46.

McTeague, L.M., Rosenberg, B.M., Lopez, J.W., Carreon, D.M., Huemer, J., Jiang, Y., Chick, C.F., Eickhoff, S.B., Etkin, A. (2020) Identification of Common Neural Circuit Disruptions in Emotional Processing Across Psychiatric Disorders. American Journal of Psychiatry:appi.ajp.2019.1-appi.ajp.2019.1.

Moher, D., Liberati, A., Tetzlaff, J., Altman, D.G., Group, P. (2009) Preferred reporting items for systematic reviews and meta-analyses: the PRISMA statement. PLoS Med, 6:e1000097.

Morawetz, C., Riedel, M.C., Salo, T., Berboth, S., Eickhoff, S., Laird, A.R., Kohn, N. (2020) Multiple largescale neural networks underlying emotion regulation. Neuroscience \& Biobehavioral Reviews.

Morris, R.W., Sparks, A., Mitchell, P.B., Weickert, C.S., Green, M.J. (2012) Lack of cortico-limbic coupling in bipolar disorder and schizophrenia during emotion regulation. Transl Psychiatry, 2:e90.

Mulej Bratec, S., Xie, X., Schmid, G., Doll, A., Schilbach, L., Zimmer, C., Wohlschlager, A., Riedl, V., Sorg, C. (2015) Cognitive emotion regulation enhances aversive prediction error activity while reducing emotional responses. Neuroimage, 123:138-48.

Mulej Bratec, S., Xie, X., Wang, Y., Schilbach, L., Zimmer, C., Wohlschlager, A.M., Riedl, V., Sorg, C. (2017) Cognitive emotion regulation modulates the balance of competing influences on ventral striatal aversive prediction error signals. Neuroimage, 147:650-657.

Müller, V.I., Cieslik, E.C., Laird, A.R., Fox, P.T., Radua, J., Mataix-Cols, D., Tench, C.R., Yarkoni, T., Nichols, T.E., Turkeltaub, P.E. (2018) Ten simple rules for neuroimaging meta-analysis. Neuroscience \& Biobehavioral Reviews, 84:151-161.

Muller, V.I., Cieslik, E.C., Serbanescu, I., Laird, A.R., Fox, P.T., Eickhoff, S.B. (2017) Altered Brain Activity in Unipolar Depression Revisited: Meta-analyses of Neuroimaging Studies. JAMA Psychiatry, 74:47-55.

Navas, J.F., Contreras-Rodriguez, O., Verdejo-Roman, J., Perandres-Gomez, A., Albein-Urios, N., Verdejo-Garcia, A., Perales, J.C. (2017) Trait and neurobiological underpinnings of negative emotion regulation in gambling disorder. Addiction, 112:1086-1094.

New, A.S., Fan, J., Murrough, J.W., Liu, X., Liebman, R.E., Guise, K.G., Tang, C.Y., Charney, D.S. (2009) A functional magnetic resonance imaging study of deliberate emotion regulation in resilience and posttraumatic stress disorder. Biol Psychiatry, 66:656-64. 
Nichols, T.E. (2012) Multiple testing corrections, nonparametric methods, and random field theory. Neuroimage, 62:811-815.

Nickl-Jockschat, T., Janouschek, H., Eickhoff, S.B., Eickhoff, C.R. (2015) Lack of Meta-Analytic Evidence for an Impact of $<$ em $>\mathrm{COMT}</ \mathrm{em}>$ Val158Met Genotype on Brain Activation During Working Memory Tasks. Biological Psychiatry, 78:e43-e46.

Ochsner, K.N., Gross, J.J. (2005) The cognitive control of emotion. Trends in cognitive sciences, 9:242249.

Ochsner, K.N., Gross, J.J. (2008) Cognitive emotion regulation: Insights from social cognitive and affective neuroscience. Current directions in psychological science, 17:153-158.

Ochsner, K.N., Silvers, J.A., Buhle, J.T. (2012) Functional imaging studies of emotion regulation: a synthetic review and evolving model of the cognitive control of emotion. Annals of the New York Academy of Sciences, 1251:E1-E24.

Opel, N., Goltermann, J., Hermesdorf, M., Berger, K., Baune, B.T., Dannlowski, U. (2020) Cross-Disorder Analysis of Brain Structural Abnormalities in Six Major Psychiatric Disorders - A Secondary Analysis of Mega- and Meta-Analytical Findings from the ENIGMA Consortium. Biological Psychiatry.

Ortner, C.N.M., Marie, M.S., Corno, D. (2016) Cognitive costs of reappraisal depend on both emotional stimulus intensity and individual differences in habitual reappraisal. PloS one, 11.

Petersen, N., Ghahremani, D.G., Rapkin, A.J., Berman, S.M., Liang, L., London, E.D. (2018) Brain activation during emotion regulation in women with premenstrual dysphoric disorder. Psychol Med, 48:1795-1802.

Phillips, M.L., Ladouceur, C.D., Drevets, W.C. (2008) A neural model of voluntary and automatic emotion regulation: implications for understanding the pathophysiology and neurodevelopment of bipolar disorder. Molecular psychiatry, 13:833-857.

Pico-Perez, M., Radua, J., Steward, T., Menchon, J.M., Soriano-Mas, C. (2017) Emotion regulation in mood and anxiety disorders: A meta-analysis of fMRI cognitive reappraisal studies. Prog Neuropsychopharmacol Biol Psychiatry, 79:96-104.

Radke, S., Hoffstaedter, F., Loffler, L., Kogler, L., Schneider, F., Blechert, J., Derntl, B. (2018) Imaging the up's and down's of emotion regulation in lifetime depression. Brain Imaging Behav, 12:156-167.

Radua, J., Mataix-Cols, D., Phillips, M.L., El-Hage, W., Kronhaus, D., Cardoner, N., Surguladze, S. (2012) A new meta-analytic method for neuroimaging studies that combines reported peak coordinates and statistical parametric maps. European psychiatry, 27:605-611.

Reinecke, A., Filippini, N., Berna, C., Western, D.G., Hanson, B., Cooper, M.J., Taggart, P., Harmer, C.J. (2015) Effective emotion regulation strategies improve fMRI and ECG markers of psychopathology in panic disorder: implications for psychological treatment action. Transl Psychiatry, 5:e673.

Rive, M.M., van Rooijen, G., Veltman, D.J., Phillips, M.L., Schene, A.H., Ruhé, H.G. (2013) Neural correlates of dysfunctional emotion regulation in major depressive disorder. A systematic review of neuroimaging studies. Neuroscience \& Biobehavioral Reviews, 37:2529-2553.

Roiser, J.P., Sahakian, B.J. (2013) Hot and cold cognition in depression. CNS spectrums, 18:139-149. 
Rubin-Falcone, H., Weber, J., Kishon, R., Ochsner, K., Delaparte, L., Doré, B., Raman, S., Denny, B.T., Oquendo, M.A., Mann, J.J. (2020) Neural predictors and effects of cognitive behavioral therapy for depression: the role of emotional reactivity and regulation. Psychological medicine, 50:146-160.

Rubin-Falcone, H., Weber, J., Kishon, R., Ochsner, K., Delaparte, L., Doré, B., Zanderigo, F., Oquendo, M.A., Mann, J.J., Miller, J.M. (2018) Longitudinal effects of cognitive behavioral therapy for depression on the neural correlates of emotion regulation. Psychiatry Research: Neuroimaging, 271:82-90.

Samea, F., Soluki, S., Nejati, V., Zarei, M., Cortese, S., Eickhoff, S.B., Tahmasian, M., Eickhoff, C.R. (2019) Brain alterations in children/adolescents with ADHD revisited: A neuroimaging meta-analysis of 96 structural and functional studies. Neurosci Biobehav Rev, 100:1-8.

Schulze, L., Domes, G., Kruger, A., Berger, C., Fleischer, M., Prehn, K., Schmahl, C., Grossmann, A., Hauenstein, K., Herpertz, S.C. (2011) Neuronal correlates of cognitive reappraisal in borderline patients with affective instability. Biol Psychiatry, 69:564-73.

Schwartz, F., Tahmasian, M., Maier, F., Rochhausen, L., Schnorrenberg, K.L., Samea, F., Seemiller, J., Zarei, M., Sorg, C., Drzezga, A., Timmermann, L., Meyer, T.D., van Eimeren, T., Eggers, C. (2019) Overlapping and distinct neural metabolic patterns related to impulsivity and hypomania in Parkinson's disease. Brain Imaging Behav, 13:241-254.

Shao, J., Myers, N., Yang, Q., Feng, J., Plant, C., Bohm, C., Forstl, H., Kurz, A., Zimmer, C., Meng, C., Riedl, V., Wohlschlager, A., Sorg, C. (2012) Prediction of Alzheimer's disease using individual structural connectivity networks. Neurobiol Aging, 33:2756-65.

Sheline, Y.I., Barch, D.M., Price, J.L., Rundle, M.M., Vaishnavi, S.N., Snyder, A.Z., Mintun, M.A., Wang, S., Coalson, R.S., Raichle, M.E. (2009) The default mode network and self-referential processes in depression. Proceedings of the National Academy of Sciences, 106:1942-1947.

Sheppes, G., Scheibe, S., Suri, G., Radu, P., Blechert, J., Gross, J.J. (2014) Emotion regulation choice: A conceptual framework and supporting evidence. Journal of Experimental Psychology: General, 143:163.

Sheppes, G., Suri, G., Gross, J.J. (2015) Emotion regulation and psychopathology. Annual review of clinical psychology, 11:379-405.

Silvers, J.A., Buhle, J.T., Ochsner, K.N. (2014) The neuroscience of emotion regulation: Basic mechanisms and their role in development, aging, and psychopathology.

Silvers, J.A., Weber, J., Wager, T.D., Ochsner, K.N. (2015) Bad and worse: neural systems underlying reappraisal of high-and low-intensity negative emotions. Social Cognitive and Affective Neuroscience, 10:172-179.

Smoski, M.J., Keng, S.L., Schiller, C.E., Minkel, J., Dichter, G.S. (2013) Neural mechanisms of cognitive reappraisal in remitted major depressive disorder. J Affect Disord, 151:171-7.

Stephanou, K., Davey, C.G., Kerestes, R., Whittle, S., Harrison, B.J. (2017) Hard to look on the bright side: neural correlates of impaired emotion regulation in depressed youth. Social cognitive and affective neuroscience, 12:1138-1148.

Sussman, T.J., Heller, W., Miller, G.A., Mohanty, A. (2013) Emotional distractors can enhance attention. Psychological science, 24:2322-2328. 
Tahmasian, M., Noori, K., Samea, F., Zarei, M., Spiegelhalder, K., Eickhoff, S.B., Van Someren, E., Khazaie, H., Eickhoff, C.R. (2018a) A lack of consistent brain alterations in insomnia disorder: An activation likelihood estimation meta-analysis. Sleep Med Rev, 42:111-118.

Tahmasian, M., Sepehry, A.A., Samea, F., Khodadadifar, T., Soltaninejad, Z., Javaheripour, N., Khazaie, H., Zarei, M., Eickhoff, S.B., Eickhoff, C.R. (2019) Practical recommendations to conduct a neuroimaging meta-analysis for neuropsychiatric disorders. Human brain mapping, 40:5142-5154.

Tahmasian, M., Zarei, M., Noori, K., Khazaie, H., Samea, F., Spiegelhalder, K., Eickhoff, S.B., Van Someren, E., Eickhoff, C.R. (2018b) Reply to Hua Liu, HaiCun Shi and PingLei Pan: Coordinate based meta-analyses in a medium sized literature: Considerations, limitations and road ahead. Sleep Med Rev, 42:236-238.

Talairach, J. (1988) 3-Dimensional proportional system: an approach to cerebral imaging. Co-planar stereotaxic atlas of the human brain.

Taylor, S.F., Liberzon, I. (2007) Neural correlates of emotion regulation in psychopathology. Trends in cognitive sciences, 11:413-418.

Thorsen, A.L., de Wit, S.J., de Vries, F.E., Cath, D.C., Veltman, D.J., van der Werf, Y.D., Mataix-Cols, D., Hansen, B., Kvale, G., van den Heuvel, O.A. (2019) Emotion Regulation in Obsessive-Compulsive Disorder, Unaffected Siblings, and Unrelated Healthy Control Participants. Biol Psychiatry Cogn Neurosci Neuroimaging, 4:352-360.

Townsend, J.D., Torrisi, S.J., Lieberman, M.D., Sugar, C.A., Bookheimer, S.Y., Altshuler, L.L. (2013) Frontal-amygdala connectivity alterations during emotion downregulation in bipolar I disorder. Biol Psychiatry, 73:127-35.

Turkeltaub, P.E., Eickhoff, S.B., Laird, A.R., Fox, M., Wiener, M., Fox, P. (2012) Minimizing withinexperiment and within-group effects in activation likelihood estimation meta-analyses. Human brain mapping, 33:1-13.

van der Meer, L., Swart, M., van der Velde, J., Pijnenborg, G., Wiersma, D., Bruggeman, R., Aleman, A. (2014) Neural correlates of emotion regulation in patients with schizophrenia and non-affected siblings. PLoS One, 9:e99667.

van Zutphen, L., Siep, N., Jacob, G.A., Domes, G., Sprenger, A., Willenborg, B., Goebel, R., Arntz, A. (2018) Always on guard: emotion regulation in women with. Journal of Psychiatry \& Neuroscience, 43:37-47.

Wang, H.-Y., Zhang, X.-X., Si, C.-P., Xu, Y., Liu, Q., Bian, H.-T., Zhang, B.-W., Li, X.-L., Yan, Z.-R. (2018) Prefrontoparietal dysfunction during emotion regulation in anxiety disorder: a meta-analysis of functional magnetic resonance imaging studies. Neuropsychiatric disease and treatment, 14:1183.

Wang, X., Zhou, X., Dai, Q., Ji, B., Feng, Z. (2017) The Role of Motivation in Cognitive Reappraisal for Depressed Patients. Front Hum Neurosci, 11:516.

Whittle, S., Yücel, M., Yap, M.B., Allen, N.B. (2011) Sex differences in the neural correlates of emotion: evidence from neuroimaging. Biological psychology, 87:319-333.

Xie, X., Mulej Bratec, S., Schmid, G., Meng, C., Doll, A., Wohlschlager, A., Finke, K., Forstl, H., Zimmer, C., Pekrun, R., Schilbach, L., Riedl, V., Sorg, C. (2016) How do you make me feel better? Social cognitive emotion regulation and the default mode network. Neuroimage, 134:270-280. 
Xiong, K., Zhang, Y., Qiu, M., Zhang, J., Sang, L., Wang, L., Xie, B., Wang, J., Li, M. (2013) Negative emotion regulation in patients with posttraumatic stress disorder. PLoS One, 8:e81957.

Zhang, L., Ai, H., Opmeer, E.M., Marsman, J.C., van der Meer, L., Ruhe, H.G., Aleman, A., van Tol, M.J. (2020) Distinct temporal brain dynamics in bipolar disorder and schizophrenia during emotion regulation. Psychol Med, 50:413-421.

Zilverstand, A., Parvaz, M.A., Goldstein, R.Z. (2017) Neuroimaging cognitive reappraisal in clinical populations to define neural targets for enhancing emotion regulation. A systematic review. Neurolmage, 151:105-116.

Ziv, M., Goldin, P.R., Jazaieri, H., Hahn, K.S., Gross, J.J. (2013) Emotion regulation in social anxiety disorder: behavioral and neural responses to three socio-emotional tasks. Biol Mood Anxiety Disord, 3:20. 
Figure 1. Study selection strategy flow chart

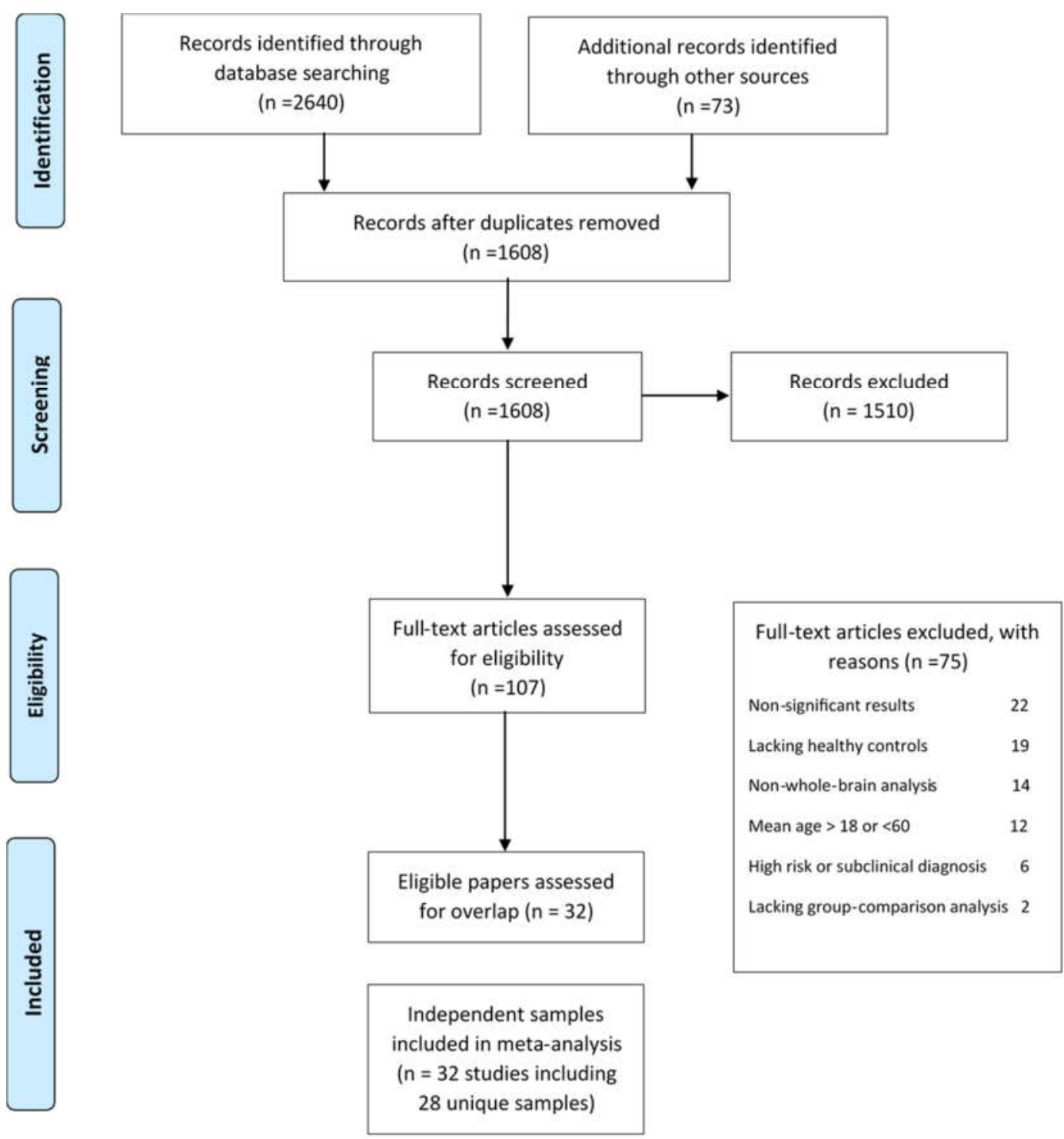


Figure 2. Distribution of the included peak coordinates in the current study. The represented foci reflect functional alterations related to reappraisal tasks in patients with various psychiatric disorders compared to healthy subjects.

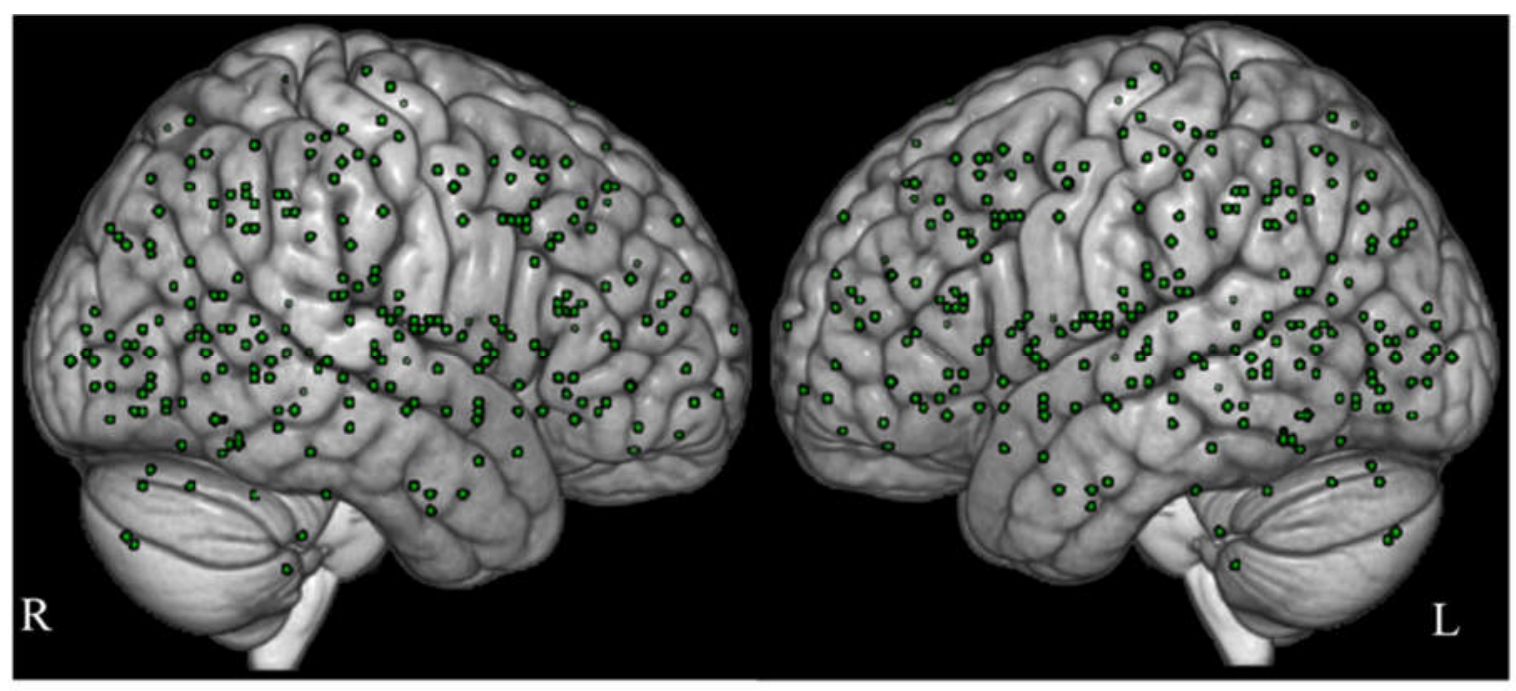


Table 1. Characteristics of 32 included studies in the present meta-analysis.

Abbreviations: MADRS (Montgomery-Asberg Depression Rating Scale), BDI (Beck Depression Inventory), HAMD (Hamilton Depression Rating Scale), PANASS

(Positive and Negative Syndrome Scale), LSAS-SR (Liebowitz Social Anxiety Scale - Self-Report), PDS (Posttraumatic Diagnostic Scale), CAPS (Clinician-

Administered PTSD Scale), YMRS (Young Mania Rating Scale), QIDS (Quick Inventory of Depressive Symptomatology), BSL (Borderline Symptom List), ALS

(Affect Lability Scale), BAI (Beck Anxiety Inventory), QASIS (Overall Anxiety Severity and Impairment Scale), HADS (Hospital Anxiety and Depression Scale),

DRSP (Daily Record of Severity of Problems), OCI-R (Obsessive Compulsive Inventory-Revised), UPPS (urgency, premeditation, perseverance and sensation

seeking scale).

\begin{tabular}{|c|c|c|c|c|c|c|c|c|c|c|c|c|c|c|}
\hline \multirow{2}{*}{ Study } & \multicolumn{2}{|c|}{ Number (M: F) } & \multicolumn{2}{|c|}{ Mean age (SD) } & \multirow{2}{*}{ Diagnosis } & \multirow{2}{*}{$\begin{array}{l}\text { Medication } \\
\text { (n) }\end{array}$} & \multirow{2}{*}{$\begin{array}{c}\text { Comorbidity } \\
\text { (n) }\end{array}$} & \multirow{2}{*}{$\begin{array}{l}\text { Symptom } \\
\text { severity }\end{array}$} & \multirow{2}{*}{$\begin{array}{l}\text { ER tactic / } \\
\text { direction }\end{array}$} & \multirow{2}{*}{ Stimulus } & \multirow{2}{*}{ Arousal/valence } & \multirow{2}{*}{$\begin{array}{l}\text { Statistical } \\
\text { threshold }\end{array}$} & \multirow{2}{*}{ Software } & \multirow{2}{*}{ MRI } \\
\hline & Patients & Controls & Patients & Controls & & & & & & & & & & \\
\hline \multicolumn{15}{|c|}{ Major Depressive Disorder (MDD) } \\
\hline $\begin{array}{l}\text { (Stephanou } \\
\text { et al., 2017) }\end{array}$ & $\begin{array}{l}53(22: \\
31)\end{array}$ & $\begin{array}{c}64(24: \\
40)\end{array}$ & $\begin{array}{l}19.72 \\
(2.68)\end{array}$ & $\begin{array}{l}19.03 \\
(2.45)\end{array}$ & SCID-IV & $\begin{array}{l}\text { No (within } \\
\text { last } 4 \\
\text { weeks) }\end{array}$ & $\begin{array}{c}\text { No } \\
\text { (lifetime) }\end{array}$ & $\begin{array}{c}\text { MADRS } \\
{[\mathrm{MDD}=32.80} \\
(4.80) ; \text { controls } \\
=2.14(2.99)]\end{array}$ & $\begin{array}{l}\text { Reinterpretation/ } \\
\text { Down- } \\
\text { regulation }\end{array}$ & $\begin{array}{l}\text { IAPS (negative } \\
\text { social scenes), EPS, } \\
\text { online sources }\end{array}$ & NA & FDR & SPM 8 & $3 \mathrm{~T}$ \\
\hline $\begin{array}{l}\text { (Wang et al., } \\
\text { 2017) }\end{array}$ & $12(5: 7)$ & $15(7: 8)$ & $\begin{array}{l}29.50 \\
(8.46)\end{array}$ & $\begin{array}{l}25.80 \\
(5.89)\end{array}$ & SCID-IV & $\begin{array}{l}\text { No (within } \\
\text { last two } \\
\text { weeks) }\end{array}$ & $\begin{array}{l}\text { No (current } \\
\text { psychiatric } \\
\text { and lifetime } \\
\text { neurologic) }\end{array}$ & $\begin{array}{c}\text { BDI [MDD = } \\
26.17(12.65) ; \\
\text { controls }=4.27 \\
(4.23)]\end{array}$ & $\begin{array}{l}\text { Reinterpretation- } \\
\text { Distancing/ } \\
\text { Down- and up- } \\
\text { regulation } \\
\end{array}$ & $\begin{array}{l}\text { IAPS (positive and } \\
\text { negative images), } \\
\text { other sources }\end{array}$ & NA & $\begin{array}{l}\text { FWE (REST, } \\
\text { AlphaSim) }\end{array}$ & SPM 8 & $3 \mathrm{~T}$ \\
\hline $\begin{array}{l}\text { (Radke et al., } \\
\text { 2018) }\end{array}$ & $\begin{array}{l}22(13: \\
9)\end{array}$ & $\begin{array}{l}22(13: \\
9)\end{array}$ & $\begin{array}{c}32.6 \\
(10.9)\end{array}$ & $\begin{array}{l}34.5 \\
(9.9)\end{array}$ & SCID-IV & 15 & 3 & $\begin{array}{c}\text { BDI [MDD = } \\
13.8(9.5) ; \\
\text { controls = 2.7 } \\
(3.4)]\end{array}$ & $\begin{array}{l}\text { Distancing/ Up- } \\
\text { regulation }\end{array}$ & $\begin{array}{l}\text { FACES (angry } \\
\text { face) }\end{array}$ & NA & FWE & SPM 8 & $3 \mathrm{~T}$ \\
\hline $\begin{array}{l}\text { (Greening et } \\
\text { al., 2014) }\end{array}$ & $\begin{array}{l}19(6: \\
13)\end{array}$ & $\begin{array}{l}19(6: \\
13)\end{array}$ & $\begin{array}{l}26.79 \\
(11.4)\end{array}$ & $\begin{array}{l}27.63 \\
(11.0)\end{array}$ & SCID-IV & 9 & 7 & $\begin{array}{c}\text { BDI }[\mathrm{MDD}= \\
25.53(10.4) ; \\
\text { controls = 1.6 } \\
\quad(2.3)]\end{array}$ & $\begin{array}{l}\text { Reinterpretation/ } \\
\text { Down- } \\
\text { regulation }\end{array}$ & $\begin{array}{l}\text { IAPS (sad and } \\
\text { positive scenes) }\end{array}$ & $\begin{array}{c}\text { Normative mean } \\
\text { arousal sad }= \\
5.08(.62) ; \text { mean } \\
\text { arousal positive }= \\
5.03(.55)\end{array}$ & $\begin{array}{c}\text { FWE } \\
\text { (AlphaSim) }\end{array}$ & AFNI 2012 & $3 \mathrm{~T}$ \\
\hline $\begin{array}{l}\text { (Smoski et } \\
\text { al., 2013) }\end{array}$ & $\begin{array}{l}18(4: \\
15)\end{array}$ & $\begin{array}{l}19(7: \\
12)\end{array}$ & $\begin{array}{l}24.5 \\
(5.4)\end{array}$ & $\begin{array}{l}27.9 \\
(6.3)\end{array}$ & SCID-IV & 5 & No (current) & $\begin{array}{c}\text { BDI [MDD = } \\
2.9(5.0) ; \\
\text { controls = } 1.4 \\
(2.4)]\end{array}$ & $\begin{array}{l}\text { Reinterpretation- } \\
\text { Distancing/ } \\
\text { Down- } \\
\text { regulation }\end{array}$ & $\begin{array}{l}\text { IAPS (sad pictures), } \\
\text { other normed } \\
\text { images }\end{array}$ & NA & $\begin{array}{l}\text { FWE (AFNI, } \\
\text { 3dClustSim) }\end{array}$ & FSL & $3 \mathrm{~T}$ \\
\hline $\begin{array}{l}\text { (Heller et al., } \\
\text { 2009) }\end{array}$ & $\begin{array}{l}27(12: \\
15)\end{array}$ & $\begin{array}{l}19(9: \\
10)\end{array}$ & $\begin{array}{l}31.48 \\
(11.58)\end{array}$ & $\begin{array}{l}31.84 \\
(14.65)\end{array}$ & DSM-IV & $\begin{array}{c}\text { No } \\
\text { (lifetime) }\end{array}$ & $\begin{array}{l}\text { No (current } \\
\text { psychiatric } \\
\text { and lifetime } \\
\text { bipolar/ } \\
\text { anxiety) }\end{array}$ & $\begin{array}{c}\text { HAMD [MDD } \\
=20.6(2.39) ; \\
\text { controls }=1.2 \\
\quad(1.6)]\end{array}$ & $\begin{array}{l}\text { Reinterpretation- } \\
\text { Distancing/ } \\
\text { Down- and up- } \\
\text { regulation }\end{array}$ & $\begin{array}{l}\text { IAPS (positive and } \\
\text { negative pictures) }\end{array}$ & $\begin{array}{l}\text { Normative mean } \\
\text { valence negative } \\
=2.95(.87) ; \\
\text { mean arousal } \\
\text { negative }=5.44 \\
\quad(.8) ; \text { mean } \\
\text { valence positive } \\
=7.13(.62) ; \\
\text { mean arousal }\end{array}$ & $\begin{array}{c}\text { FWE } \\
\text { (AlphaSim) }\end{array}$ & AFNI & $3 \mathrm{~T}$ \\
\hline
\end{tabular}




\begin{tabular}{|c|c|c|c|c|c|c|c|c|c|c|c|c|c|c|}
\hline & & & & & & & & & & & $\begin{array}{c}\text { positive }=5.28 \\
(.58)\end{array}$ & & & \\
\hline $\begin{array}{l}\text { (Sheline et } \\
\text { al., 2009) }\end{array}$ & $\begin{array}{l}24(12: \\
12)\end{array}$ & $\begin{array}{l}21(6: \\
15)\end{array}$ & $34(9.4)$ & $35(7.3)$ & DSM-IV & $\begin{array}{l}\text { No (within } \\
\text { last } 4 \\
\text { weeks) }\end{array}$ & No (lifetime) & $\begin{array}{l}\text { HAMD [MDD } \\
=21(3.5) ; \\
\text { controls }=0 \\
(.04)]\end{array}$ & $\begin{array}{l}\text { Reinterpretation- } \\
\text { Distancing/ } \\
\text { Down- } \\
\text { regulation }\end{array}$ & $\begin{array}{l}\text { IAPS (positive and } \\
\text { negative pictures) }\end{array}$ & NA & NA & NA & $3 \mathrm{~T}$ \\
\hline $\begin{array}{l}\text { (Johnstone et } \\
\text { al., 2007) }\end{array}$ & $\begin{array}{l}21(8: \\
13)\end{array}$ & $\begin{array}{l}28(7: \\
21)\end{array}$ & $33(12)$ & $28(12)$ & DSM-IV & $\begin{array}{c}\text { No } \\
\text { (current) }\end{array}$ & $\begin{array}{l}\text { No (current } \\
\text { psychiatric } \\
\text { and lifetime } \\
\text { bipolar) }\end{array}$ & $\begin{array}{c}\text { HAMD [MDD } \\
=21(2.5) ; \\
\text { controls }=.5 \\
\quad(.6)]\end{array}$ & $\begin{array}{l}\text { Reinterpretation- } \\
\text { Distancing/ } \\
\text { Down- and up- } \\
\text { regulation }\end{array}$ & $\begin{array}{l}\text { IAPS (positive and } \\
\text { negative pictures) }\end{array}$ & $\begin{array}{c}\text { Normative mean } \\
\text { valence negative } \\
=2.95(.87) ; \\
\text { mean arousal } \\
\text { negative }=5.44 \\
(.8) ; \text { mean } \\
\text { valence positive } \\
=7.13(.62) ; \\
\text { mean arousal } \\
\text { positive }=5.28 \\
(.58) \\
\end{array}$ & $\begin{array}{c}\text { FWE } \\
\text { (AlphaSim) }\end{array}$ & AFNI & $3 \mathrm{~T}$ \\
\hline \multicolumn{15}{|c|}{ Schizophrenia } \\
\hline $\begin{array}{c}\text { (Zhang et al., } \\
\text { 2020) }\end{array}$ & $\begin{array}{l}16(12: \\
4)\end{array}$ & $\begin{array}{l}15(10: \\
5)\end{array}$ & $\begin{array}{l}31.75 \\
(8.7)\end{array}$ & $\begin{array}{l}33.60 \\
(11.1)\end{array}$ & $\begin{array}{c}\text { DSM-IV } \\
\text { and ICD- } \\
10\end{array}$ & NA & No (current) & $\begin{array}{c}\text { PANSS } \\
\text { [schizophrenia } \\
=26.69(7.1)]\end{array}$ & $\begin{array}{l}\text { Reinterpretation/ } \\
\text { Down- } \\
\text { regulation }\end{array}$ & $\begin{array}{l}\text { IAPS (negative } \\
\text { pictures) }\end{array}$ & NA & $\begin{array}{l}\text { FWE (AFNI } \\
\text { 2018, } \\
\text { 3dClustSim) }\end{array}$ & SPM 12 & $3 \mathrm{~T}$ \\
\hline $\begin{array}{l}\text { (Larabi et al., } \\
\text { 2018) }\end{array}$ & $\begin{array}{l}30(22: \\
8)\end{array}$ & $\begin{array}{l}15(10: \\
5)\end{array}$ & $\begin{array}{c}35 \\
(10.16)\end{array}$ & $\begin{array}{c}33.6 \\
(11.11)\end{array}$ & $\begin{array}{l}\text { DSM-IV } \\
\text { and ICD- } \\
10\end{array}$ & 28 & No (current) & $\begin{array}{c}\text { PANSS } \\
\text { [schizophrenia } \\
=57.9(14.71)]\end{array}$ & $\begin{array}{l}\text { Reinterpretation/ } \\
\text { Down- } \\
\text { regulation }\end{array}$ & $\begin{array}{l}\text { IAPS (negative } \\
\text { images) }\end{array}$ & $\begin{array}{l}\text { Normative mean } \\
\text { valence negative } \\
\quad=2.6 ; \text { mean } \\
\text { arousal negative } \\
\quad=5.7 ; \text { mean } \\
\text { valence neutral }= \\
1.3 ; \text { mean arousal } \\
\text { neutral }=1.9\end{array}$ & FWE & SPM 12 & $3 \mathrm{~T}$ \\
\hline $\begin{array}{l}\text { (van der } \\
\text { Meer et al., } \\
\text { 2014) }\end{array}$ & $\begin{array}{l}20(14: \\
6)\end{array}$ & $\begin{array}{l}20(16: \\
4)\end{array}$ & $\begin{array}{c}35.5 \\
(11.7)\end{array}$ & $\begin{array}{c}35.2 \\
(10.8)\end{array}$ & $\begin{array}{l}\text { DSM-IV } \\
\text { and ICD- } \\
\quad 10\end{array}$ & 20 & NA & $\begin{array}{c}\text { PANSS } \\
\text { [schizophrenia } \\
=29.9(7.7)]\end{array}$ & $\begin{array}{l}\text { Reinterpretation/ } \\
\text { Down- } \\
\text { regulation }\end{array}$ & $\begin{array}{l}\text { IAPS (negative } \\
\text { images) }\end{array}$ & $\begin{array}{l}\text { Normative mean } \\
\text { valence negative } \\
\quad=2.6 ; \text { mean } \\
\text { arousal negative } \\
\quad=5.7 ; \text { mean } \\
\text { valence neutral }= \\
1.3 ; \text { mean arousal } \\
\text { neutral }=1.9\end{array}$ & FWE & SPM 5 & $3 \mathrm{~T}$ \\
\hline $\begin{array}{l}\text { (Morris et } \\
\text { al., 2012) }\end{array}$ & $12(8: 4)$ & $15(6: 9)$ & $44(3)$ & $35(2)$ & DSM-IV & 12 & NA & $\begin{array}{c}\text { PANSS } \\
\text { [schizophrenia } \\
=32(2)]\end{array}$ & $\begin{array}{l}\text { Distancing/ } \\
\text { Down- and up- } \\
\text { regulation }\end{array}$ & $\begin{array}{l}\text { IAPS (negative } \\
\text { threat and suffering } \\
\text { images) }\end{array}$ & NA & FWE & SPM 8 & $3 \mathrm{~T}$ \\
\hline
\end{tabular}




\begin{tabular}{|c|c|c|c|c|c|c|c|c|c|c|c|c|c|c|}
\hline $\begin{array}{l}\text { (Ziv et al., } \\
\text { 2013) }\end{array}$ & $\begin{array}{l}27(15: \\
12)\end{array}$ & $\begin{array}{l}27(14: \\
13)\end{array}$ & $\begin{array}{l}31.1 \\
(7.6)\end{array}$ & $\begin{array}{l}32.6 \\
(9.5)\end{array}$ & DSM-IV & $\begin{array}{c}\text { No } \\
\text { (current) }\end{array}$ & 8 & $\begin{array}{c}\text { LSAS-SR } \\
{[\mathrm{SAD}=99.3} \\
(11.8) ; \text { controls } \\
=15.3(9.1)]\end{array}$ & $\begin{array}{l}\text { Reinterpretation/ } \\
\text { Down- } \\
\text { regulation }\end{array}$ & $\begin{array}{l}\text { Anger and contempt } \\
\text { facial expressions }\end{array}$ & NA & $\begin{array}{c}\text { FWE } \\
\text { (AlphaSim) }\end{array}$ & AFNI & $3 \mathrm{~T}$ \\
\hline $\begin{array}{l}\text { (Goldin et } \\
\text { al., 2009a) }\end{array}$ & $15(6: 9)$ & $17(8: 9)$ & $\begin{array}{l}31.6 \\
(9.7)\end{array}$ & $\begin{array}{l}32.1 \\
(9.3)\end{array}$ & DSM-IV & $\begin{array}{c}\text { No } \\
\text { (current) }\end{array}$ & $\begin{array}{l}\text { No (current } \\
\text { psychiatric } \\
\text { and lifetime } \\
\text { neurologic) }\end{array}$ & $\begin{array}{c}\text { LSAS-SR } \\
{[\mathrm{SAD}=67.6} \\
(21.1) ; \text { controls } \\
=29.3(20.9)]\end{array}$ & $\begin{array}{l}\text { Distancing/ } \\
\text { Down- } \\
\text { regulation }\end{array}$ & $\begin{array}{l}\text { Facial Action } \\
\text { Coding System } \\
\text { (angry and } \\
\text { contempt facial } \\
\text { expression), and } \\
\text { physical threat } \\
\text { scenes } \\
\end{array}$ & NA & $\begin{array}{c}\text { FWE } \\
\text { (AlphaSim) }\end{array}$ & AFNI & $3 \mathrm{~T}$ \\
\hline $\begin{array}{l}\text { (Goldin et } \\
\text { al., 2009a) }\end{array}$ & $\begin{array}{l}27(15: \\
12)\end{array}$ & $\begin{array}{l}27(15: \\
12)\end{array}$ & $\begin{array}{l}32.1 \\
(9.2)\end{array}$ & $\begin{array}{l}32.2 \\
(9.5)\end{array}$ & DSM-IV & $\begin{array}{c}\text { No } \\
\text { (current) }\end{array}$ & 6 & $\begin{array}{c}\text { LSAS-SR } \\
{[\mathrm{SAD}=80.1} \\
(16.8) ; \text { controls } \\
=15.7(8.7)]\end{array}$ & $\begin{array}{l}\text { Reinterpretation/ } \\
\text { Down- } \\
\text { regulation }\end{array}$ & $\begin{array}{l}\text { Written social } \\
\text { situations }\end{array}$ & NA & $\begin{array}{c}\text { FWE } \\
\text { (AlphaSim) }\end{array}$ & AFNI & $3 \mathrm{~T}$ \\
\hline \multicolumn{15}{|c|}{ Post-traumatic Stress Disorder (PTSD) } \\
\hline $\begin{array}{c}\text { (Butler et al., } \\
\text { 2018) }\end{array}$ & $\begin{array}{l}18(18: \\
0)\end{array}$ & $\begin{array}{l}27(27: \\
0)\end{array}$ & $\begin{array}{l}28.3 \\
(6.4)\end{array}$ & $\begin{array}{l}32.7 \\
(5.9)\end{array}$ & ICD-10 & $\begin{array}{c}\text { No } \\
\text { (current) }\end{array}$ & $\begin{array}{l}\text { No (lifetime } \\
\text { axis-II) }\end{array}$ & $\begin{array}{c}\text { PDS [PTSD = } \\
36.28(10.65) ; \\
\text { controls = 15.7 } \\
(8.7)] \\
\end{array}$ & $\begin{array}{l}\text { Reinterpretation/ } \\
\text { Down- } \\
\text { regulation }\end{array}$ & Combat images & NA & $\begin{array}{l}\text { FWE (AFNI } \\
\text { 2016, } \\
\text { 3dClustSim) }\end{array}$ & SPM 8 & $3 \mathrm{~T}$ \\
\hline $\begin{array}{c}\text { (Xiong et al., } \\
\text { 2013) }\end{array}$ & $\begin{array}{l}20(13: \\
7)\end{array}$ & $\begin{array}{l}20(14: \\
6)\end{array}$ & $\begin{array}{l}32.92 \\
(8.48)\end{array}$ & $\begin{array}{l}31.53 \\
(7.43)\end{array}$ & SCID-IV & $\begin{array}{c}\text { No } \\
\text { (lifetime) }\end{array}$ & $\begin{array}{l}\text { No (lifetime, } \\
\text { except of } \\
\text { past } \\
\text { depression) }\end{array}$ & $\begin{array}{c}\text { CAPS [PTSD = } \\
52.33(9.44) ; \\
\text { controls }=8.26 \\
(9.31)]\end{array}$ & $\begin{array}{l}\text { Reinterpretation/ } \\
\text { Down- and up- } \\
\text { regulation }\end{array}$ & $\begin{array}{l}\text { IAPS (negative } \\
\text { images) }\end{array}$ & $\begin{array}{c}\text { Normative mean } \\
\text { valence negative } \\
=2.17(.34) ; \\
\text { mean arousal } \\
\text { negative }=6.23 \\
\quad(26) ; \text { mean } \\
\text { valence neutral = } \\
5.12(1.04) ; \text { mean } \\
\text { arousal neutral = } \\
4.18(.72)\end{array}$ & $\begin{array}{c}\text { FWE (REST, } \\
\text { AlphaSim) }\end{array}$ & SPM 8 & $3 \mathrm{~T}$ \\
\hline $\begin{array}{l}\text { (New et al., } \\
\text { 2009) }\end{array}$ & $\begin{array}{l}14(0: \\
14)\end{array}$ & $\begin{array}{l}14(0: \\
14)\end{array}$ & $\begin{array}{c}38.7 \\
(11.2)\end{array}$ & $\begin{array}{c}31.7 \\
(10.3)\end{array}$ & SCID-IV & $\begin{array}{c}\text { No } \\
\text { (lifetime) }\end{array}$ & $\begin{array}{l}\text { No (lifetime, } \\
\text { except of } \\
\text { past } \\
\text { depression) }\end{array}$ & $\begin{array}{c}\text { CAPS [PTSD = } \\
69.1(17.6)]\end{array}$ & $\begin{array}{l}\text { Reinterpretation/ } \\
\text { Down- and up- } \\
\text { regulation }\end{array}$ & $\begin{array}{l}\text { IAPS (negative } \\
\text { images) }\end{array}$ & NA & $\begin{array}{c}\text { FWE (REST, } \\
\text { AlphaSim) }\end{array}$ & SPM 2 & $3 \mathrm{~T}$ \\
\hline \multicolumn{15}{|c|}{ Bipolar Disorder (BD) } \\
\hline $\begin{array}{c}\text { (Zhang et al., } \\
\text { 2020) }\end{array}$ & $15(6: 9)$ & $\begin{array}{l}15(10: \\
5)\end{array}$ & $\begin{array}{l}39.87 \\
(12.5)\end{array}$ & $\begin{array}{l}33.60 \\
(11.1)\end{array}$ & $\begin{array}{l}\text { DSM-IV } \\
\text { and ICD- } \\
10\end{array}$ & NA & No (current) & $\begin{array}{c}\text { YMRS }[\mathrm{BD}= \\
1.4(1.5)] \text { and } \\
\text { QIDS }[\mathrm{BD}= \\
5.27(5.4)]\end{array}$ & $\begin{array}{l}\text { Reinterpretation/ } \\
\text { Down- } \\
\text { regulation }\end{array}$ & $\begin{array}{l}\text { IAPS (negative } \\
\text { pictures) }\end{array}$ & NA & $\begin{array}{l}\text { FWE (AFNI } \\
\text { 2018, } \\
\text { 3dClustSim) }\end{array}$ & SPM 12 & $3 \mathrm{~T}$ \\
\hline $\begin{array}{l}\text { (Townsend } \\
\text { et al., 2013) }\end{array}$ & $\begin{array}{l}30(19: \\
11)\end{array}$ & $\begin{array}{l}26(15: \\
11)\end{array}$ & $\begin{array}{c}37.9 \\
(12.6)\end{array}$ & $\begin{array}{c}35.5 \\
(12.4)\end{array}$ & SCID-IV & 21 & $\begin{array}{l}\text { No (current } \\
\text { psychiatric } \\
\text { and lifetime }\end{array}$ & $\begin{array}{c}\text { YMRS }[\mathrm{BD}= \\
1.7(2.2)] \text { and } \\
\text { HAMD }[\mathrm{BD}= \\
3.8(1.9)]\end{array}$ & $\begin{array}{l}\text { Reinterpretation/ } \\
\text { Down- } \\
\text { regulation }\end{array}$ & $\begin{array}{l}\text { IAPS (negative } \\
\text { images) }\end{array}$ & $\begin{array}{l}\text { Normative mean } \\
\text { valence negative } \\
\quad=2.8 ; \text { mean }\end{array}$ & NA & FSL & $3 \mathrm{~T}$ \\
\hline
\end{tabular}




\begin{tabular}{|c|c|c|c|c|c|c|c|c|c|c|c|c|c|c|}
\hline & & & & & & & $\begin{array}{c}\text { substance } \\
\text { use/abuse) }\end{array}$ & & & & $\begin{array}{c}\text { arousal negative } \\
=6.5\end{array}$ & & & \\
\hline $\begin{array}{l}\text { (Morris et } \\
\text { al., 2012) }\end{array}$ & $13(8: 5)$ & $15(6: 9)$ & $41(3)$ & $35(2)$ & DSM-IV & 13 & NA & NA & $\begin{array}{l}\text { Distancing/ } \\
\text { Down- } \\
\text { regulation }\end{array}$ & $\begin{array}{c}\text { IAPS (negative } \\
\text { threat and suffering } \\
\text { images) }\end{array}$ & NA & FWE & SPM 8 & $3 \mathrm{~T}$ \\
\hline \multicolumn{15}{|c|}{ Borderline Personality Disorder (BPD) } \\
\hline $\begin{array}{l}\text { (van Zutphen } \\
\text { et al., 2018) }\end{array}$ & $\begin{array}{l}55(0: \\
55)\end{array}$ & $\begin{array}{c}42(0: \\
42)\end{array}$ & $\begin{array}{l}30.88 \\
(8.78)\end{array}$ & $\begin{array}{l}28.33 \\
(10.50)\end{array}$ & SCID-IV & 55 & 49 & $\begin{array}{c}\text { BPD checklist } \\
{[\mathrm{BPD}=120.6} \\
(26.92) ; \\
\text { controls }= \\
50.73(5.03)]\end{array}$ & $\begin{array}{l}\text { Reinterpretation/ } \\
\text { Down- and up- } \\
\text { regulation }\end{array}$ & $\begin{array}{l}\text { IAPS (negative and } \\
\text { positive), } \\
\text { additional erotic } \\
\text { pictures }\end{array}$ & NA & FWE & BrainVoyager & $3 \mathrm{~T}$ \\
\hline $\begin{array}{l}\text { (Schulze et } \\
\text { al., 2011) }\end{array}$ & $\begin{array}{l}15(0: \\
15)\end{array}$ & $15(0: 15)$ & $\begin{array}{l}27.60 \\
(7.85)\end{array}$ & $\begin{array}{l}24.53 \\
(2.85)\end{array}$ & SCID-IV & NA & 7 & $\begin{array}{c}\text { BSL [BPD = } \\
183.87(53.64) ; \\
\text { controls = } \\
49.60(16.04)]\end{array}$ & $\begin{array}{l}\text { Distancing/ } \\
\text { Down- and up- } \\
\text { regulation }\end{array}$ & $\begin{array}{l}\text { IAPS (negative } \\
\text { threat and suffering } \\
\text { images) }\end{array}$ & NA & FWE & SPM 5 & $\begin{array}{c}1.5 \\
\mathrm{~T}\end{array}$ \\
\hline $\begin{array}{l}\text { (Koenigsberg } \\
\text { et al., 2009) }\end{array}$ & $\begin{array}{l}18(8: \\
10)\end{array}$ & $16(9: 9)$ & $\begin{array}{c}32.6 \\
(10.4)\end{array}$ & $\begin{array}{l}31.8 \\
(7.7)\end{array}$ & SCID-IV & $\begin{array}{l}\text { No (within } \\
\text { last } 4 \\
\text { weeks) }\end{array}$ & No (lifetime) & $\begin{array}{c}\text { ALS [BPD }= \\
94.9(23.7) ; \\
\text { controls = 20.3 } \\
\quad(16.0)]\end{array}$ & $\begin{array}{l}\text { Distancing/ } \\
\text { Down- } \\
\text { regulation }\end{array}$ & $\begin{array}{l}\text { IAPS (interpersonal } \\
\text { situations) }\end{array}$ & $\begin{array}{l}\text { Normative mean } \\
\text { valence negative } \\
\quad=2.35 ; \text { mean } \\
\text { arousal negative } \\
\quad=5.9 ; \text { mean } \\
\text { valence neutral = } \\
5.2 ; \text { mean arousal } \\
\text { neutral }=3.65\end{array}$ & $\begin{array}{l}\text { FWE (REST, } \\
\text { AlphaSim) }\end{array}$ & SPM 2 & $3 \mathrm{~T}$ \\
\hline \multicolumn{15}{|c|}{ Miscellaneous Anxiety Disorders } \\
\hline $\begin{array}{l}\text { (Blair et al., } \\
\text { 2012) }\end{array}$ & $\begin{array}{l}53(17: \\
36)\end{array}$ & $\begin{array}{l}18(8: \\
10)\end{array}$ & $\begin{array}{l}33.73 \\
(9.99)\end{array}$ & $\begin{array}{c}33.4 \\
(9.65)\end{array}$ & SCID-IV & $\begin{array}{l}\text { No (within } \\
\text { last } 6 \\
\text { months) }\end{array}$ & No (current) & $\begin{array}{c}\text { BAI } \\
\text { [miscellaneous } \\
=10.93(7.17) ; \\
\text { controls }=2.3 \\
(2.02)]\end{array}$ & $\begin{array}{l}\text { Reinterpretation/ } \\
\text { Down- } \\
\text { regulation }\end{array}$ & $\begin{array}{c}\text { IAPS (positive and } \\
\text { negative images) }\end{array}$ & $\begin{array}{l}\text { Normative mean } \\
\text { valence negative } \\
=3.08 ; \text { mean } \\
\text { arousal negative } \\
=5.43 \text {; mean } \\
\text { valence positive } \\
=7.21 ; \text { mean } \\
\text { arousal positive }= \\
5.15\end{array}$ & $\begin{array}{c}\text { FWE } \\
\text { (AlphaSim) }\end{array}$ & AFNI & $\begin{array}{c}1.5 \\
\mathrm{~T}\end{array}$ \\
\hline $\begin{array}{l}\text { (Ball et al., } \\
\text { 2013) }\end{array}$ & $\begin{array}{l}41(9: \\
32)\end{array}$ & $\begin{array}{l}22(11: \\
11)\end{array}$ & $32(9)$ & $27(9)$ & DSM-IV & $\begin{array}{l}\text { No (within } \\
\text { last } 2 \\
\text { weeks) }\end{array}$ & 17 & $\begin{array}{c}\text { QASIS } \\
\text { [miscellaneous } \\
=8.6(3.3) ; \\
\text { controls }=.8 \\
(1.2)] \\
\end{array}$ & $\begin{array}{l}\text { Reinterpretation- } \\
\text { Distancing/ } \\
\text { Down- } \\
\text { regulation }\end{array}$ & $\begin{array}{l}\text { IAPS (negative } \\
\text { images) }\end{array}$ & NA & $\begin{array}{c}\text { FWE } \\
\text { (3dClustSim) }\end{array}$ & AFNI & $3 \mathrm{~T}$ \\
\hline $\begin{array}{l}\text { (Campbell- } \\
\text { Sills et al., } \\
\text { 2011) }\end{array}$ & $\begin{array}{l}13(2: \\
11)\end{array}$ & $\begin{array}{l}13(2: \\
11)\end{array}$ & NA & NA & SCID-IV & $\begin{array}{c}\text { No } \\
\text { (lifetime) }\end{array}$ & 12 & NA & $\begin{array}{l}\text { Reinterpretation/ } \\
\text { Down- } \\
\text { regulation }\end{array}$ & $\begin{array}{l}\text { IAPS (negative } \\
\text { images) }\end{array}$ & NA & $\begin{array}{c}\text { FWE } \\
\text { (AlphaSim) }\end{array}$ & AFNI & $3 \mathrm{~T}$ \\
\hline
\end{tabular}




\begin{tabular}{|c|c|c|c|c|c|c|c|c|c|c|c|c|c|c|}
\hline $\begin{array}{l}\text { (Reinecke et } \\
\text { al., 2015) }\end{array}$ & $\begin{array}{l}18(4: \\
14)\end{array}$ & $\begin{array}{l}18(4: \\
14)\end{array}$ & $\begin{array}{c}36.5 \\
(13.8)\end{array}$ & $\begin{array}{c}32.3 \\
(12.1)\end{array}$ & SCID-IV & 3 & 13 & $\begin{array}{l}\text { HADS-Anxiety } \\
\quad[\mathrm{PD}=14.6 \\
(4.1) ; \text { controls } \\
\quad=2.0(1.6)]\end{array}$ & $\begin{array}{l}\text { Reinterpretation/ } \\
\text { Down- } \\
\text { regulation }\end{array}$ & $\begin{array}{l}\text { IAPS (accidents or } \\
\text { funerals) }\end{array}$ & $\begin{array}{l}\text { Normative mean } \\
\text { valence negative } \\
=2.8(1.7) ; \text { mean } \\
\text { arousal negative } \\
=6.0(2.2)\end{array}$ & NA & FSL & $3 \mathrm{~T}$ \\
\hline \multicolumn{15}{|c|}{ Pre-menstrual Dysphoric Disorder (PMDD) } \\
\hline $\begin{array}{l}\text { (Petersen et } \\
\text { al., 2018) }\end{array}$ & $\begin{array}{l}18(0: \\
18)\end{array}$ & $\begin{array}{l}18(0: \\
18)\end{array}$ & $\begin{array}{l}29.2 \\
(7.24)\end{array}$ & $\begin{array}{c}25.4 \\
(6.99)\end{array}$ & SCID-IV & $\begin{array}{c}\text { No } \\
\text { (current) }\end{array}$ & $\begin{array}{l}\text { No (lifetime } \\
\text { except of } \\
\text { unipolar } \\
\text { mood } \\
\text { disorders) }\end{array}$ & $\begin{array}{c}\text { DRSP [PMDD } \\
=3.53(.63) ; \\
\text { controls }=1.01 \\
\quad(.05)]\end{array}$ & $\begin{array}{l}\text { Distancing/ } \\
\text { Down- } \\
\text { regulation }\end{array}$ & $\begin{array}{l}\text { IAPS (negative } \\
\text { images) and other } \\
\text { ones }\end{array}$ & NA & NA & FSL & $3 \mathrm{~T}$ \\
\hline \multicolumn{15}{|c|}{ Obsession-Compulsion Disorder (OCD) } \\
\hline $\begin{array}{l}\text { (Thorsen et } \\
\text { al., 2019) }\end{array}$ & $\begin{array}{l}43(21: \\
22)\end{array}$ & $\begin{array}{l}38(18: \\
20)\end{array}$ & $\begin{array}{c}37.58 \\
(10)\end{array}$ & $\begin{array}{l}39.05 \\
(11.27)\end{array}$ & SCID-IV & $\begin{array}{l}\text { No (within } \\
\text { last } 4 \\
\text { weeks) }\end{array}$ & 29 & $\begin{array}{c}\text { OCI-R [OCD = } \\
24.67(11.79) ; \\
\text { controls }=3.37 \\
(4.71)]\end{array}$ & $\begin{array}{l}\text { Reinterpretation- } \\
\text { Distancing/ } \\
\text { Down- } \\
\text { regulation } \\
\end{array}$ & $\begin{array}{l}\text { Fearful and OCD- } \\
\text { related pictures }\end{array}$ & NA & NA & SPM 8 & $3 \mathrm{~T}$ \\
\hline \multicolumn{15}{|c|}{ Substance Use Disorder (SUD) } \\
\hline $\begin{array}{l}\text { (Albein- } \\
\text { Urios et al., } \\
\text { 2014) }\end{array}$ & $\begin{array}{l}17(16: \\
1)\end{array}$ & $\begin{array}{l}18(17: \\
1)\end{array}$ & $\begin{array}{l}36.41 \\
(5.99)\end{array}$ & $\begin{array}{l}30.50 \\
(4.64)\end{array}$ & SCID-IV & NA & $\begin{array}{l}\text { NO (current } \\
\text { psychiatric } \\
\text { and lifetime } \\
\text { neurologic) }\end{array}$ & $\begin{array}{c}\text { UPPS-Negative } \\
\text { urgency [SUD } \\
=33.17(6.51) \\
\text { controls }= \\
22.22(5.1)]\end{array}$ & $\begin{array}{l}\text { Reinterpretation- } \\
\text { Distancing/ } \\
\text { Down- } \\
\text { regulation }\end{array}$ & $\begin{array}{l}\text { IAPS (negative } \\
\text { images) }\end{array}$ & $\begin{array}{c}\text { Normative mean } \\
\text { valence negative } \\
=3.51(.86) ; \\
\text { mean arousal } \\
\text { negative }=5.70 \\
(0.6)\end{array}$ & FDR & SPM 8 & $3 \mathrm{~T}$ \\
\hline \multicolumn{15}{|c|}{ Gambling Disorder (GD) } \\
\hline $\begin{array}{l}\text { (Navas et al., } \\
\text { 2017) }\end{array}$ & $\begin{array}{c}17(16: \\
1)\end{array}$ & $\begin{array}{l}21(20: \\
1)\end{array}$ & $\begin{array}{l}32.94 \\
(7.77)\end{array}$ & $31(4.6)$ & SCID-IV & NA & $\begin{array}{l}\text { No (current } \\
\text { psychiatric } \\
\text { and lifetime } \\
\text { neurologic) }\end{array}$ & $\begin{array}{c}\text { UPPS-Negative } \\
\text { urgency [GD = } \\
29.18(4.7) ; \\
\text { controls }= \\
23.19(5.46)]\end{array}$ & $\begin{array}{l}\text { Reinterpretation/ } \\
\text { Down- } \\
\text { regulation }\end{array}$ & $\begin{array}{l}\text { IAPS (negative } \\
\text { mutilation pictures) }\end{array}$ & $\begin{array}{c}\text { Normative mean } \\
\text { valence negative } \\
=3.51(.86) ; \\
\text { mean arousal } \\
\text { negative }=5.70 \\
(0.6)\end{array}$ & $\begin{array}{c}\text { FWE (REST, } \\
\text { AlphaSim) }\end{array}$ & SPM 8 & $3 \mathrm{~T}$ \\
\hline
\end{tabular}


Table 2. Findings of conducted meta-analyses in patients compared to healthy subjects. Abbreviations: ALE (Activation Likelihood Estimation), TFCE (Threshold-Free Cluster Enhancement), cFWE (clusterlevel Family-Wise Error). *Since at least 17 experiments provide sufficient power for statistical analysis, some subanalyses were not performed.

\begin{tabular}{|c|c|c|c|c|c|}
\hline \multirow{2}{*}{ Domain } & \multirow{2}{*}{ ALE } & \multirow{2}{*}{ Contrast } & \multicolumn{2}{|c|}{ P-value } & \multirow{2}{*}{$\begin{array}{l}\text { Number of } \\
\text { experiments }\end{array}$} \\
\hline & & & TFCE & cFWE & \\
\hline \multirow{5}{*}{ Task } & Reappraisal & All & .406 & .418 & 28 \\
\hline & Reappraisal & Patients $<$ & .436 & .570 & 21 \\
\hline & & Controls & & & \\
\hline & Reappraisal & Patients > & .675 & .832 & 20 \\
\hline & & Controls & & & \\
\hline \multirow{2}{*}{ Regulation direction } & Down-regulation & All & .662 & .859 & 27 \\
\hline & *Up-regulation & All & $\mathrm{n} / \mathrm{s}$ & $n / s$ & $9<17$ \\
\hline \multirow{2}{*}{ Stimulus valence } & Negative & All & .615 & .930 & 28 \\
\hline & ${ }^{*}$ Positive & All & $\mathrm{n} / \mathrm{s}$ & $\mathrm{n} / \mathrm{s}$ & $3<17$ \\
\hline \multirow{4}{*}{ Disorder category } & Mood and Anxiety & All & .120 & .076 & 20 \\
\hline & ${ }^{*}$ Mood & All & $\mathrm{n} / \mathrm{s}$ & $n / s$ & $10<17$ \\
\hline & ${ }^{*}$ Anxiety & All & $\mathrm{n} / \mathrm{s}$ & $\mathrm{n} / \mathrm{s}$ & $10<17$ \\
\hline & ${ }^{*}$ Others & All & $\mathrm{n} / \mathrm{s}$ & $\mathrm{n} / \mathrm{s}$ & $8<17$ \\
\hline \multirow{4}{*}{ Reappraisal tactic } & ${ }^{*}$ Reinterpretation & All & $\mathrm{n} / \mathrm{s}$ & $\mathrm{n} / \mathrm{s}$ & $14<17$ \\
\hline & *Distancing & All & $\mathrm{n} / \mathrm{s}$ & $\mathrm{n} / \mathrm{s}$ & $7<17$ \\
\hline & ${ }^{*}$ Reinterpretation- & All & $\mathrm{n} / \mathrm{s}$ & $\mathrm{n} / \mathrm{s}$ & $7<17$ \\
\hline & Distancing & & & & \\
\hline
\end{tabular}


Table S1. List of excluded studies with reasons

\begin{tabular}{|c|c|}
\hline No Study & Reason of exclusion \\
\hline (Kreifelts et al., 2017) & Non-significant results \\
\hline (Fitzgerald et al., 2017a) & Non-significant results \\
\hline (Corbalán et al., 2015) & Non-significant results \\
\hline (Gaebler et al., 2014) & Non-significant results \\
\hline (Dillon and Pizzagalli, 2013) & Non-significant results \\
\hline (Rubin-Falcone et al., 2020) & Non-significant results \\
\hline (Dixon et al., 2020) & Non-significant results \\
\hline (Jansen et al., 2019b) & Non-significant results \\
\hline (Jansen et al., 2019a) & Non-significant results \\
\hline $10 \quad$ (Loeffler et al., 2019) & Non-significant results \\
\hline (Chrysikou et al., 2019) & Non-significant results \\
\hline $12 \quad$ Materna et al., 2019) & Non-significant results \\
\hline $13 \quad$ (Davis et al., 2018) & Non-significant results \\
\hline 14 (Doré et al., 2018) & Non-significant results \\
\hline $15 \quad$ (Rubin-Falcone et al., 2018) & Non-significant results \\
\hline $16 \quad$ (Denny et al., 2015) & Non-significant results \\
\hline $17 \quad$ (Wang et al., 2014) & Non-significant results \\
\hline $18 \quad$ (Albein-Urios et al., 2013) & Non-significant results \\
\hline $19 \quad$ (Fitzgerald et al., 2017b) & Non-significant results \\
\hline $20 \quad$ (Schmitt et al., 2016) & Non-significant results \\
\hline $21 \quad$ (Light et al., 2011) & Non-significant results \\
\hline $22 \quad$ (Yip et al., 2018) & Non-significant results \\
\hline $23 \quad$ (Hilland et al., 2018) & Lacking healthy controls \\
\hline $24 \quad$ (Zhang et al., 2020) & Lacking healthy controls \\
\hline
\end{tabular}




\begin{tabular}{|c|c|c|}
\hline & (Contreras-Rodríguez et al., 2020) & Lacking healthy controls \\
\hline 26 & (Fitzgerald et al., 2019) & Lacking healthy controls \\
\hline 27 & (Schmitgen et al., 2019) & Lacking healthy controls \\
\hline 28 & (Gorka et al., 2019) & Lacking healthy controls \\
\hline 29 & (Klumpp et al., 2017b) & Lacking healthy controls \\
\hline 30 & (Fonzo et al., 2017b) & Lacking healthy controls \\
\hline 31 & (Fonzo et al., 2017a) & Lacking healthy controls \\
\hline 32 & (Klumpp et al., 2017a) & Lacking healthy controls \\
\hline 33 & (Reinecke et al., 2018) & Lacking healthy controls \\
\hline 34 & (Klumpp et al., 2017c) & Lacking healthy controls \\
\hline 35 & (Goldin et al., 2014) & Lacking healthy controls \\
\hline 36 & (Reinecke et al., 2014) & Lacking healthy controls \\
\hline & (Brühl et al., 2013) & Lacking healthy controls \\
\hline & (Goldin et al., 2013a) & Lacking healthy controls \\
\hline & (Heller et al., 2013) & Lacking healthy controls \\
\hline & (Goldin et al., 2013b) & Lacking healthy controls \\
\hline & (Hermann et al., 2009) & Lacking healthy controls \\
\hline & (Kanske et al., 2015) & Non-whole-brain analysis \\
\hline & (Rabinak et al., 2014) & Non-whole-brain analysis \\
\hline & (Kanske et al., 2012) & Non-whole-brain analysis \\
\hline & (Lang et al., 2012) & Non-whole-brain analysis \\
\hline & (Erk et al., 2010) & Non-whole-brain analysis \\
\hline & (Douw et al., 2020) & Non-whole-brain analysis \\
\hline & (Klumpp et al., 2019) & Non-whole-brain analysis \\
\hline & (Jacob et al., 2019) & Non-whole-brain analysis \\
\hline & (Young et al., 2019) & Non-whole-brain analysis \\
\hline & (Zhang et al., 2018) & Non-whole-brain analysis \\
\hline & (Rive et al., 2015) & Non-whole-brain analysis \\
\hline
\end{tabular}




\begin{tabular}{|c|c|}
\hline $53 \quad$ (De Wit et al., 2015) & Non-whole-brain analysis \\
\hline $54 \quad$ (Ball et al., 2014) & Non-whole-brain analysis \\
\hline $55 \quad$ (Hermann et al., 2013) & Non-whole-brain analysis \\
\hline $\begin{array}{ll}56 & \text { (Raschle et al., 2019) }\end{array}$ & Mean age $<18$ or $>60$ \\
\hline $57 \quad$ (Seidel et al., 2018b) & Mean age $<18$ or $>60$ \\
\hline $\begin{array}{ll}58 & \text { (Seidel et al., 2018a) }\end{array}$ & Mean age $<18$ or $>60$ \\
\hline 59 (LeWinn et al., 2018) & Mean age $<18$ or $>60$ \\
\hline $60 \quad$ (Cisler et al., 2016) & Mean age $<18$ or $>60$ \\
\hline 61 (Murphy et al., 2016) & Mean age $\geq 18$ or $\leq 60$ \\
\hline $\begin{array}{ll}62 & \text { (Belden et al., 2015) }\end{array}$ & Mean age $<18$ or $>60$ \\
\hline $63 \quad$ (Platt et al., 2015) & Mean age $<18$ or $>60$ \\
\hline 64 (Karim et al., 2017) & Mean age $<18$ or $>60$ \\
\hline $\begin{array}{ll}65 & \text { (Pitskel et al., 2014) }\end{array}$ & Mean age $<18$ or $>60$ \\
\hline $66 \quad$ (Andreescu et al., 2015) & Mean age $<18$ or $>60$ \\
\hline $67 \quad$ (Perlman et al., 2012) & Mean age $<18$ or $>60$ \\
\hline $68 \quad$ (Meluken et al., 2019) & High risk or subclinical diagnosis \\
\hline $69 \quad$ (Simsek et al., 2017) & High risk or subclinical diagnosis \\
\hline $70 \quad$ (Van Der Velde et al., 2015) & High risk or subclinical diagnosis \\
\hline $71 \quad$ (Heissler et al., 2014) & High risk or subclinical diagnosis \\
\hline $72 \quad$ (Felder et al., 2012) & High risk or subclinical diagnosis \\
\hline $73 \quad$ (Modinos et al., 2010) & High risk or subclinical diagnosis \\
\hline $74 \quad$ (Walsh et al., 2019) & Lacking group-comparison analysis \\
\hline $75 \quad$ (Anand et al., 2019) & Lacking group-comparison analysis \\
\hline
\end{tabular}

1. Kreifelts B, Brück C, Ethofer T, Ritter J, Weigel L, Erb M, et al. (2017): Prefrontal mediation of emotion regulation in social anxiety disorder during laughter perception. Neuropsychologia. 96:175-183. 
2. Fitzgerald JM, MacNamara A, Kennedy AE, Rabinak CA, Rauch SA, Liberzon I, et al. (2017): Individual differences in cognitive reappraisal use and emotion regulatory brain function in combat-exposed veterans with and without PTSD. Depression and anxiety. 34:79-88.

3. Corbalán F, Beaulieu S, Armony J (2015): Emotion regulation in bipolar disorder type I: an fMRI study. Psychological medicine. 45:2521-2531.

4. Gaebler M, Daniels JK, Lamke J-P, Fydrich T, Walter H (2014): Behavioural and neural correlates of self-focused emotion regulation in social anxiety disorder. Journal of psychiatry \& neuroscience: JPN. 39:249.

5. Dillon DG, Pizzagalli DA (2013): Evidence of successful modulation of brain activation and subjective experience during reappraisal of negative emotion in unmedicated depression. Psychiatry Research: Neuroimaging. 212:99-107.

6. Rubin-Falcone H, Weber J, Kishon R, Ochsner K, Delaparte L, Doré B, et al. (2020): Neural predictors and effects of cognitive behavioral therapy for depression: the role of emotional reactivity and regulation. Psychological medicine. 50:146-160.

7. Dixon ML, Moodie CA, Goldin PR, Farb N, Heimberg RG, Gross JJ (2020): Emotion Regulation in Social Anxiety Disorder: Reappraisal and Acceptance of Negative Self-beliefs. Biological Psychiatry: Cognitive Neuroscience and Neuroimaging. 5:119-129.

8. Jansen JM, van den Heuvel OA, van der Werf YD, de Wit SJ, Veltman DJ, van den Brink W, et al. (2019): The effect of high-frequency repetitive transcranial magnetic stimulation on emotion processing, reappraisal, and craving in alcohol use disorder patients and healthy controls: a functional magnetic resonance imaging study. Frontiers in psychiatry. 10.

9. Jansen JM, Van Den Heuvel O, van der Werf YD, De Wit SJ, Veltman DJ, Van Den Brink W, et al. (2019): Emotion processing, reappraisal and craving in alcohol dependence: a functional Magnetic Resonance Imaging study. Frontiers in psychiatry. 10:227.

10. Loeffler LAK, Satterthwaite TD, Habel U, Schneider F, Radke S, Derntl B (2019): Attention control and its emotion-specific association with cognitive emotion regulation in depression. Brain imaging and behavior. 13:1766-1779.

11. Chrysikou EG, Wing EK, van Dam WO (2019): Transcranial Direct Current Stimulation Over Prefrontal Cortex in Depression Modulates Cortical Excitability in Emotion Regulation Regions as Measured by Concurrent Functional Magnetic Resonance Imaging: An Exploratory Study. Biological Psychiatry: Cognitive Neuroscience and Neuroimaging.

12. Materna L, Wiesner CD, Shushakova A, Trieloff J, Weber N, Engell A, et al. (2019): Adult patients with ADHD differ from healthy controls in implicit, but not explicit, emotion regulation. Journal of psychiatry \& neuroscience: JPN. 44:340.

13. Davis EG, Foland-Ross LC, Gotlib IH (2018): Neural correlates of top-down regulation and generation of negative affect in major depressive disorder. Psychiatry Research: Neuroimaging. 276:1-8.

14. Doré BP, Rodrik O, Boccagno C, Hubbard A, Weber J, Stanley B, et al. (2018): Negative autobiographical memory in depression reflects elevated amygdala-hippocampal reactivity and hippocampally associated emotion regulation. Biological Psychiatry: Cognitive Neuroscience and Neuroimaging. 3:358-366. 
15. Rubin-Falcone H, Weber J, Kishon R, Ochsner K, Delaparte L, Doré B, et al. (2018): Longitudinal effects of cognitive behavioral therapy for depression on the neural correlates of emotion regulation. Psychiatry Research: Neuroimaging. 271:82-90.

16. Denny BT, Fan J, Liu X, Ochsner KN, Guerreri S, Mayson SJ, et al. (2015): Elevated amygdala activity during reappraisal anticipation predicts anxiety in avoidant personality disorder. Journal of affective disorders. 172:1-7.

17. Wang X, Feng Z, Zhou D, Lei X, Liao T, Zhang L, et al. (2014): Dissociable self effects for emotion regulation: a study of chinese major depressive outpatients. BioMed research international. 2014.

18. Albein-Urios N, Verdejo-Román J, Soriano-Mas C, Asensio S, Martínez-González JM, VerdejoGarcía A (2013): Cocaine users with comorbid Cluster B personality disorders show dysfunctional brain activation and connectivity in the emotional regulation networks during negative emotion maintenance and reappraisal. European Neuropsychopharmacology. 23:1698-1707.

19. Fitzgerald JM, Phan KL, Kennedy AE, Shankman SA, Langenecker SA, Klumpp H (2017): Prefrontal and amygdala engagement during emotional reactivity and regulation in generalized anxiety disorder. Journal of affective disorders. 218:398-406.

20. Schmitt R, Winter D, Niedtfeld I, Herpertz SC, Schmahl C (2016): Effects of psychotherapy on neuronal correlates of reappraisal in female patients with borderline personality disorder. Biological Psychiatry: Cognitive Neuroscience and Neuroimaging. 1:548-557.

21. Light SN, Heller AS, Johnstone T, Kolden GG, Peterson MJ, Kalin NH, et al. (2011): Reduced right ventrolateral prefrontal cortex activity while inhibiting positive affect is associated with improvement in hedonic capacity after 8 weeks of antidepressant treatment in major depressive disorder. Biological psychiatry. 70:962-968.

22. Yip SW, Gross JJ, Chawla M, Ma S-S, Shi X-H, Liu L, et al. (2018): Is neural processing of negative stimuli altered in addiction independent of drug effects? Findings from drug-naïve youth with internet gaming disorder. Neuropsychopharmacology. 43:1364-1372.

23. Hilland E, Landrø N, Harmer C, Browning M, Maglanoc LA, Jonassen R (2018): Attentional bias modification alters fMRI response towards negative stimuli in residual depression. bioRxiv. 322842 .

24. Zhang J, Dong H, Zhao Z, Chen S, Jiang Q, Du X, et al. (2020): Altered Neural Processing of Negative Stimuli in People with Internet Gaming Disorder: fMRI Evidence from the Comparison with Recreational Game Users. Journal of Affective Disorders.

25. Contreras-Rodríguez O, Albein-Urios N, Martinez-Gonzalez JM, Menchón JM, Soriano-Mas C, Verdejo-García A (2020): The neural interface between negative emotion regulation and motivation for change in cocaine dependent individuals under treatment. Drug and Alcohol Dependence.107854.

26. Fitzgerald JM, Klumpp H, Langenecker S, Phan KL (2019): Transdiagnostic neural correlates of volitional emotion regulation in anxiety and depression. Depression and anxiety. 36:453-464.

27. Schmitgen MM, Niedtfeld I, Schmitt R, Mancke F, Winter D, Schmahl C, et al. (2019): Individualized treatment response prediction of dialectical behavior therapy for borderline personality disorder using multimodal magnetic resonance imaging. Brain and Behavior. 9:e01384.

28. Gorka SM, Young CB, Klumpp H, Kennedy AE, Francis J, Ajilore O, et al. (2019): Emotion-based brain mechanisms and predictors for SSRI and CBT treatment of anxiety and depression: a randomized trial. Neuropsychopharmacology. 44:1639-1648. 
29. Klumpp H, Roberts J, Kapella MC, Kennedy AE, Kumar A, Phan KL (2017): Subjective and objective sleep quality modulate emotion regulatory brain function in anxiety and depression. Depression and anxiety. 34:651-660.

30. Fonzo GA, Goodkind MS, Oathes DJ, Zaiko YV, Harvey M, Peng KK, et al. (2017): Selective effects of psychotherapy on frontopolar cortical function in PTSD. American Journal of Psychiatry. 174:1175-1184.

31. Fonzo GA, Goodkind MS, Oathes DJ, Zaiko YV, Harvey M, Peng KK, et al. (2017): PTSD psychotherapy outcome predicted by brain activation during emotional reactivity and regulation. American Journal of Psychiatry. 174:1163-1174.

32. Klumpp H, Fitzgerald JM, Kinney KL, Kennedy AE, Shankman SA, Langenecker SA, et al. (2017): Predicting cognitive behavioral therapy response in social anxiety disorder with anterior cingulate cortex and amygdala during emotion regulation. Neurolmage: Clinical. 15:25-34.

33. Reinecke A, Thilo KV, Croft A, Harmer CJ (2018): Early effects of exposure-based cognitive behaviour therapy on the neural correlates of anxiety. Translational psychiatry. 8:1-9.

34. Klumpp H, Roberts J, Kennedy AE, Shankman SA, Langenecker SA, Gross JJ, et al. (2017): Emotion regulation related neural predictors of cognitive behavioral therapy response in social anxiety disorder. Progress in Neuro-Psychopharmacology and Biological Psychiatry. 75:106-112.

35. Goldin PR, Ziv M, Jazaieri H, Weeks J, Heimberg RG, Gross JJ (2014): Impact of cognitivebehavioral therapy for social anxiety disorder on the neural bases of emotional reactivity to and regulation of social evaluation. Behaviour research and therapy. 62:97-106.

36. Reinecke A, Thilo K, Filippini N, Croft A, Harmer CJ (2014): Predicting rapid response to cognitivebehavioural treatment for panic disorder: the role of hippocampus, insula, and dorsolateral prefrontal cortex. Behaviour research and therapy. 62:120-128.

37. Brühl AB, Herwig U, Delsignore A, Jäncke L, Rufer M (2013): General emotion processing in social anxiety disorder: neural issues of cognitive control. Psychiatry Research: Neuroimaging. 212:108-115.

38. Goldin P, Ziv M, Jazaieri H, Hahn K, Gross JJ (2013): MBSR vs aerobic exercise in social anxiety: fMRI of emotion regulation of negative self-beliefs. Social cognitive and affective neuroscience. 8:65-72.

39. Heller AS, Johnstone T, Peterson MJ, Kolden GG, Kalin NH, Davidson RJ (2013): Increased prefrontal cortex activity during negative emotion regulation as a predictor of depression symptom severity trajectory over 6 months. JAMA psychiatry. 70:1181-1189.

40. Goldin PR, Ziv M, Jazaieri H, Hahn K, Heimberg R, Gross JJ (2013): Impact of cognitive behavioral therapy for social anxiety disorder on the neural dynamics of cognitive reappraisal of negative self-beliefs: randomized clinical trial. JAMA psychiatry. 70:1048-1056.

41. Hermann A, Schäfer A, Walter B, Stark R, Vaitl D, Schienle A (2009): Emotion regulation in spider phobia: role of the medial prefrontal cortex. Social cognitive and affective neuroscience. 4:257-267.

42. Kanske P, Schönfelder S, Forneck J, Wessa M (2015): Impaired regulation of emotion: neural correlates of reappraisal and distraction in bipolar disorder and unaffected relatives. Translational psychiatry. 5:e497-e497.

43. Rabinak CA, MacNamara A, Kennedy AE, Angstadt M, Stein MB, Liberzon I, et al. (2014): Focal and aberrant prefrontal engagement during emotion regulation in veterans with posttraumatic stress disorder. Depression and anxiety. 31:851-861. 
44. Kanske P, Heissler J, Schönfelder S, Wessa M (2012): Neural correlates of emotion regulation deficits in remitted depression: the influence of regulation strategy, habitual regulation use, and emotional valence. Neuroimage. 61:686-693.

45. Lang S, Kotchoubey B, Frick C, Spitzer C, Grabe HJ, Barnow S (2012): Cognitive reappraisal in trauma-exposed women with borderline personality disorder. Neuroimage. 59:1727-1734.

46. Erk S, Mikschl A, Stier S, Ciaramidaro A, Gapp V, Weber B, et al. (2010): Acute and sustained effects of cognitive emotion regulation in major depression. Journal of Neuroscience. 30:15726-15734.

47. Douw L, Quaak M, Fitzsimmons SM, de Wit SJ, van der Werf YD, van den Heuvel OA, et al. (2020): Static and dynamic network properties of the repetitive transcranial magnetic stimulation target predict changes in emotion regulation in obsessive-compulsive disorder. Brain stimulation. 13:318-326.

48. Klumpp H, Kinney KL, Bhaumik R, Fitzgerald JM (2019): Principal component analysis and brainbased predictors of emotion regulation in anxiety and depression. Psychological medicine. 49:2320-2329.

49. Jacob Y, Shany O, Goldin P, Gross J, Hendler T (2019): Reappraisal of interpersonal criticism in social anxiety disorder: A brain network hierarchy perspective. Cerebral Cortex. 29:3154-3167.

50. Young KS, LeBeau RT, Niles AN, Hsu KJ, Burklund LJ, Mesri B, et al. (2019): Neural connectivity during affect labeling predicts treatment response to psychological therapies for social anxiety disorder. Journal of affective disorders. 242:105-110.

51. Zhang L, Opmeer EM, van der Meer L, Aleman A, Ćurčić-Blake B, Ruhé HG (2018): Altered frontalamygdala effective connectivity during effortful emotion regulation in bipolar disorder. Bipolar disorders. 20:349-358.

52. Rive MM, Mocking RJ, Koeter MW, van Wingen G, de Wit SJ, van den Heuvel OA, et al. (2015): State-dependent differences in emotion regulation between unmedicated bipolar disorder and major depressive disorder. JAMA psychiatry. 72:687-696.

53. De Wit S, Van der Werf Y, Mataix-Cols D, Trujillo JP, Van Oppen P, Veltman D, et al. (2015): Emotion regulation before and after transcranial magnetic stimulation in obsessive compulsive disorder. Psychological Medicine. 45:3059-3073.

54. Ball TM, Stein MB, Ramsawh HJ, Campbell-Sills L, Paulus MP (2014): Single-subject anxiety treatment outcome prediction using functional neuroimaging. Neuropsychopharmacology. 39:1254-1261.

55. Hermann A, Leutgeb V, Scharmüller W, Vaitl D, Schienle A, Stark R (2013): Individual differences in cognitive reappraisal usage modulate the time course of brain activation during symptom provocation in specific phobia. Biology of mood \& anxiety disorders. 3:16.

56. Raschle NM, Fehlbaum LV, Menks WM, Martinelli A, Prätzlich M, Bernhard A, et al. (2019): Atypical Dorsolateral Prefrontal Activity in Female Adolescents With Conduct Disorder During Effortful Emotion Regulation. Biological Psychiatry: Cognitive Neuroscience and Neuroimaging. 4:984-994.

57. Seidel M, King JA, Ritschel F, Boehm I, Geisler D, Bernardoni F, et al. (2018): The real-life costs of emotion regulation in anorexia nervosa: a combined ecological momentary assessment and fMRI study. Translational psychiatry. 8:1-11.

58. Seidel M, King JA, Ritschel F, Boehm I, Geisler D, Bernardoni F, et al. (2018): Processing and regulation of negative emotions in anorexia nervosa: an fMRI study. Neurolmage: Clinical. 18:1-8. 
59. LeWinn KZ, Strigo IA, Connolly CG, Ho TC, Tymofiyeva O, Sacchet MD, et al. (2018): An exploratory examination of reappraisal success in depressed adolescents: Preliminary evidence of functional differences in cognitive control brain regions. Journal of affective disorders. 240:155-164.

60. Cisler J, Sigel B, Steele J, Smitherman S, Vanderzee K, Pemberton J, et al. (2016): Changes in functional connectivity of the amygdala during cognitive reappraisal predict symptom reduction during trauma-focused cognitive-behavioral therapy among adolescent girls with post-traumatic stress disorder. Psychological medicine. 46:3013-3023.

61. Murphy ER, Barch DM, Pagliaccio D, Luby JL, Belden AC (2016): Functional connectivity of the amygdala and subgenual cingulate during cognitive reappraisal of emotions in children with MDD history is associated with rumination. Developmental cognitive neuroscience. 18:89-100.

62. Belden AC, Pagliaccio D, Murphy ER, Luby JL, Barch DM (2015): Neural activation during cognitive emotion regulation in previously depressed compared to healthy children: Evidence of specific alterations. Journal of the American Academy of Child \& Adolescent Psychiatry. 54:771-781.

63. Platt B, Campbell CA, James AC, Murphy SE, Cooper MJ, Lau JY (2015): Cognitive reappraisal of peer rejection in depressed versus non-depressed adolescents: functional connectivity differences. Journal of psychiatric research. 61:73-80.

64. Karim H, Tudorascu D, Butters M, Walker S, Aizenstein H, Andreescu C (2017): In the grip of worry: cerebral blood flow changes during worry induction and reappraisal in late-life generalized anxiety disorder. Translational psychiatry. 7:e1204-e1204.

65. Pitskel NB, Bolling DZ, Kaiser MD, Pelphrey KA, Crowley MJ (2014): Neural systems for cognitive reappraisal in children and adolescents with autism spectrum disorder. Developmental cognitive neuroscience. 10:117-128.

66. Andreescu C, Sheu LK, Tudorascu D, Gross JJ, Walker S, Banihashemi L, et al. (2015): Emotion reactivity and regulation in late-life generalized anxiety disorder: functional connectivity at baseline and post-treatment. The American Journal of Geriatric Psychiatry. 23:200-214.

67. Perlman G, Simmons AN, Wu J, Hahn KS, Tapert SF, Max JE, et al. (2012): Amygdala response and functional connectivity during emotion regulation: a study of 14 depressed adolescents. Journal of affective disorders. 139:75-84.

68. Meluken I, Ottesen NM, Phan KL, Goldin PR, Di Simplicio M, Macoveanu J, et al. (2019): Neural response during emotion regulation in monozygotic twins at high familial risk of affective disorders. Neurolmage: Clinical. 21:101598.

69. Simsek F, Oguz K, Kitis O, Akan S, Kempton M, Gonul A (2017): Neural activation during cognitive reappraisal in girls at high risk for depression. Progress in Neuro-Psychopharmacology and Biological Psychiatry. 77:49-56.

70. Van Der Velde J, Opmeer EM, Liemburg EJ, Bruggeman R, Nieboer R, Wunderink L, et al. (2015): Lower prefrontal activation during emotion regulation in subjects at ultrahigh risk for psychosis: an fMRIstudy. npj Schizophrenia. 1:1-7.

71. Heissler J, Kanske P, Schönfelder S, Wessa M (2014): Inefficiency of emotion regulation as vulnerability marker for bipolar disorder: evidence from healthy individuals with hypomanic personality. Journal of affective disorders. 152:83-90. 
72. Felder JN, Smoski MJ, Kozink RV, Froeliger B, McClernon J, Bizzell J, et al. (2012): Neural mechanisms of subclinical depressive symptoms in women: a pilot functional brain imaging study. $B M C$ psychiatry. 12:152.

73. Modinos G, Ormel J, Aleman A (2010): Altered activation and functional connectivity of neural systems supporting cognitive control of emotion in psychosis proneness. Schizophrenia research. 118:8897.

74. Walsh EC, Eisenlohr-Moul TA, Minkel J, Bizzell J, Petty C, Crowther A, et al. (2019): Pretreatment brain connectivity during positive emotion upregulation predicts decreased anhedonia following behavioral activation therapy for depression. Journal of affective disorders. 243:188-192.

75. Anand A, Grandhi J, Karne H, Spielberg JM (2019): Intrinsic functional connectivity during continuous maintenance and suppression of emotion in bipolar disorder. Brain Imaging and Behavior.1-11. 